\title{
Spoken Sentence Comprehension in Aphasia: Event-related Potential Evidence for a Lexical Integration Deficit
}

\author{
Tamara Swaab \\ Center for Neuroscience, University of California, Davis \\ Colin Brown and Peter Hagoort \\ Max Planck Institute for Psycholinguistics, Nijmegen, \\ The Netherlands
}

\begin{abstract}
In this study the $\mathrm{N} 400$ component of the event-related potential was used to investigate spoken sentence understanding in Broca's and Wernicke's aphasics. The aim of the study was to determine whether spoken sentence comprehension problems in these patients might result from a deficit in the on-line integration of lexical information. Subjects listened to sentences spoken at a normal rate. In half of these sentences, the meaning of the final word of the sentence matched the semantic specifications of the preceding sentence context. In the other half of the sentences, the sentence-final word was anomalous with respect to the preceding sentence context. The N400 was measured to the sentence-final words in both conditions. The results for the aphasic patients $(n=14)$ were analyzed according to the severity of their comprehension deficit and compared to a group of 12 neurologically unimpaired age-matched controls, as well as a group of 6 nonaphasic patients with a lesion in the right hemisphere. The
\end{abstract}

\section{INTRODUCTION}

A number of studies have provided evidence indicating that comprehension problems in Broca's and Wernicke's aphasics might be caused by deficits in certain aspects of real-time language processing. Based on this evidence, it has been suggested that the comprehension deficits of Broca's and Wernicke's aphasics are not primarily due to a loss of stored linguistic representations, but rather are due to an inability to access and/or exploit these representations in real-time (e.g., Baum, 1989; Chenery, Ingram, \& Murdoch, 1990; Friederici \& Kilborn, 1989; Haarmann \& Kolk, 1991, 1994; Hagoort, 1993; Hagoort, Brown, \& Swaab, 1996; Linebarger, Schwartz, \& Saffran, 1983; Milberg, Blumstein, \& Dworetzky, 1987; Ostrin \& Tyler, 1993; Swinney, Zurif, \& Nicol, 1989).

The exact nature of the processing deficit in aphasic comprehenders is still a matter of debate. One possibility nonaphasic brain damaged patients and the aphasic patients with a light comprehension deficit (high comprehenders, $n=$ 7) showed an N400 effect that was comparable to that of the neurologically unimpaired subjects. In the aphasic patients with a moderate to severe comprehension deficit (low comprehenders, $n=7$ ), a reduction and delay of the N400 effect was obtained. In addition, the $\mathbf{P} 300$ component was measured in a classical oddball paradigm, in which subjects were asked to count infrequent low tones in a random series of high and low tones. No correlation was found between the occurrence of $\mathrm{N} 400$ and $\mathrm{P} 300$ effects, indicating that changes in the N400 results were related to the patients' language deficit. Overall, the pattern of results was compatible with the idea that aphasic patients with moderate to severe comprehension problems are impaired in the integration of lexical information into a higher order representation of the preceding sentence context. that has been entertained is that Broca's aphasics in particular might have an impairment in automatically accessing the semantic lexicon (e.g., Baum, 1989; Milberg et al., 1987; Milberg, Blumstein, Katz, Gershberg, \& Brown, 1995; Swinney et al., 1989). However, results from recent on-line studies suggest that rather than lexical access, the integration of lexical information into the preceding word or sentence context might be impaired in these patients (e.g., Hagoort, 1990, 1993; Hagoort et al., 1996; Swaab, Brown, \& Hagoort, 1995; Tyler \& Ostrin, 1994; Tyler, Ostrin, Cooke, \& Moss, 1995). More specifically, Hagoort (1993) has suggested that comprehension problems in Broca's and Wernicke's aphasics result from a temporal mismatch between lexical access and lexical integration, caused by a delay in the integration of lexical information within the context representation.

The possibility that a delay in the integration of lexical information underlies spoken sentence comprehension 
problems in Broca's and Wernicke's aphasics was further examined in the current study. To clarify the rationale behind this study, we first provide an overview of the mechanisms that are involved in normal sentence comprehension. Then we describe the use of event-related potentials (ERPs) to investigate real-time processing of words in sentence context. Finally, findings on comprehension problems in Broca's and Wernicke's aphasics will be summarized.

\section{Comprehending Spoken Sentences}

Most people are able to understand speech effortlessly. Nonetheless, spoken language comprehension is a very complex process that has to be executed at an amazingly high speed. The ultimate aim of the listener is to extract meaning from a spoken utterance. A crucial step in mapping sound onto meaning is that the listener recognizes words on the basis of the information contained in the continuous speech stream. This process of word recognition serves as an interface between the sensory input and the construction of a grammatical and interpretative representation of the utterance. Spoken word recognition can be broken down into three basic processes: lexical access, lexical selection, and lexical integration (Frauenfelder \& Tyler, 1987; Marslen-Wilson, 1987). In the process of lexical access, an initial stretch of the sensory input is mapped onto the representations of lexical form. This results in the activation of all lexical items that match the input. During the process of lexical selection, the number of activated lexical representations is narrowed down to the one lexical candidate that best matches the sensory input and the context specifications. Finally, the lexical integration process maps syntactic and semantic information at the lexical level onto a higher-order representation of the whole utterance. In order to be able to understand spoken sentences in a normal way, these basic processes have to be executed quickly, but in addition they need to be executed at the right moments in time.

A crucial issue in understanding sentence comprehension concerns the effects of sentence context on word processing. This issue has been addressed in a number of studies both in the visual and auditory modality by measuring monitoring times, lexical decision latencies, or ERPs to target words (e.g., Fischler \& Bloom, 1980; Kutas \& Hillyard, 1980; Moss \& Marslen-Wilson, 1993; Schwanenflugel \& Shoben, 1985; Stanovich \& West, 1983). These studies have revealed that several aspects of the sentence context influence the processing of a target word: the congruity of the word with the sentence context, the strength of the sentential constraints, and the degree to which a word is an expected completion of a particular sentence or phrase (cloze probability). Congruency, high constraint, and high cloze probability all have a positive influence on the processing of a word. On the other hand, presenting subjects with words that do not fit the semantic specifications of the preceding sentence context-semantic anomalies-adversely affects the processing of target words and interferes with the comprehenders' construction of a higher-order representation of the sentence. It is still a matter of debate how context influences word recognition, the question being whether context already exerts its influence at the level of lexical access (e.g., McClelland \& Elman, 1986) or instead only at the following stages of lexical selection (Zwitserlood, 1989) and lexical integration (e.g., Marslen-Wilson, 1987). However, for the purposes of the current study it is sufficient to note that in normal listeners lexical information is integrated within a very short period of time into an overall representation of the sentence context. The aim of this study is to investigate whether aphasic patients with comprehension deficits are capable of the same rapid integration of lexical information into sentence contexts.

\section{ERPs to Words in Sentence Context}

In this study, we recorded event-related brain potentials (ERPs) while subjects were listening to sentences. ERPs reflect the summation of synchronous postsynaptic activity of a large population of neurons engaged in information processing (e.g., Allison, Wood, \& McCarthy, 1986). ERPs are distinguished from the background electrical activity of the brain by making a time-locked average over several stimulus events. This average will typically include a number of positive and negative voltage peaks that appear at specific latencies and that have particular distributions over the scalp.

ERPs have two important characteristics that make them very suitable to study language processing deficits in aphasia (e.g., Hagoort \& Kutas, 1995). First, ERPs provide a millisecond-level temporal resolution of neural activity underlying language processes. Thus, they not only allow inferences about the types of linguistic information that these patients are (in)sensitive to, but also about possible changes in the time course of the relevant language processing events. In addition, ERPs can be recorded without imposing additional, potentially interfering task demands on the aphasic patients, other than the natural task of listening to speech for understanding.

The most relevant ERP component for this study is the $\mathrm{N} 400$, a negative peak in the waveform that is larger over centro-posterior than anterior regions of the scalp (Kutas \& Hillyard, 1983). In young adults, the $\mathbf{N} 400$ reaches its maximum amplitude between about 380 and $440 \mathrm{~ms}$ after stimulus onset. However, this may be delayed in elderly subjects (e.g., Gunter, Jackson, \& Mulder, 1992). The N400 is especially sensitive to semantic aspects of the linguistic input. This was first reported by Kutas and Hillyard (1980) who found that the amplitude of the N400 to visually presented sentence-final anomalous words ("He spread the warm bread with socks") was increased when compared to the $\mathrm{N} 400$ to sentence-final 
congruent words ("It was his first day at work"). This difference in the amplitude of the $\mathrm{N} 400$ is referred to as the $\mathrm{N} 400$ effect. In contrast to semantic anomalies, physically deviant words (e.g., printed in boldface type) elicited a positive potential rather than a negativity. Other nonsemantic deviations such as musical or grammatical violations also failed to elicit the N400 effect (Besson \& Macar, 1987; Hagoort, Brown, \& Groothusen, 1993; Kutas \& Hillyard, 1983; Osterhout \& Holcomb, 1992).

Modulations of the N400 amplitude are not restricted to semantic violations. Word expectancy, word frequency, and position of the word in the sentence are other factors that modulate the amplitude of the N400 (Van Petten \& Kutas, 1990, 1991). Furthermore, the N400 effect is also obtained when the preceding context is limited to one word (e.g., Bentin, McCarthy, \& Wood, 1985; Boddy, 1986). N400 effects are not only observed with written input, but they can also be observed when presenting subjects with naturally produced connected speech (Holcomb \& Neville, 1991).

Recent studies suggest that the N400 effect primarily reflects postlexical processes that are involved in lexical integration (Brown \& Hagoort, 1993; Chwilla, Brown, \& Hagoort, 1995; Holcomb, 1993; Rugg, Furda, \& Lorist, 1988). This implies that an $\mathrm{N} 400$ effect will occur when the lexical integration process is hampered as a result of a mismatch between the semantic specifications of a particular word and the semantic specifications of its preceding word or sentence context. Since the latency of the N400 effect can vary (Holcomb \& Neville, 1991), it provides, in principle, a sensitive measure for investigating whether comprehension problems in Broca's and Wernicke's aphasics might be related to changes in the time course of lexical integration.

\section{Comprehension Deficits in Aphasia}

A central issue in studies of aphasia is whether comprehension deficits in aphasic patients are due to a loss of stored linguistic information or, alternatively, to a disruption of the processes that act upon the linguistic input. Although classically aphasic deficits have been attributed to loss of semantic (e.g., Goodglass \& Baker, 1976; Grober, Perecman, Kellar, \& Brown, 1980; Zurif, Caramazza, Myerson, \& Galvin, 1974) or syntactic knowledge structures (Berndt \& Caramazza, 1980), in recent years an increasing number of studies have reported results that are suggestive of a processing impairment rather than a loss of knowledge (i.e., a representational deficit). Two types of results have been of central importance for this change of perspective.

In their seminal paper, Linebarger et al. (1983) reported that four Broca's aphasics who had shown almost no syntactic understanding in a sentence-picture matching task, were able to reliably distinguish syntactically well-formed sentences from syntactically incorrect sentences in a grammaticality judgment task that involved a variety of syntactic structures. This result suggests that the nature of the task is of direct influence on the performance of the aphasic patients, and moreover, that under certain task conditions the Broca's aphasics were able to access and exploit structural knowledge. The observed variability in performance on these different tasks supports the idea that agrammatic comprehension results from a processing deficit rather than from a representational deficit. Other studies have provided additional evidence for this idea (e.g., Baum, 1989; Blumstein, Milberg, Dworetzky, Rosen, \& Gershberg, 1991; Friederici \& Frazier, 1992; Haarmann \& Kolk, 1994; Lukatela, Crain, \& Shankweiler, 1988; Shankweiler, Crain, Gorrell, \& Tuller, 1989).

In another series of studies, the classical notion of a loss of semantic knowledge in Wernicke's aphasics (e.g., Goodglass \& Baker, 1976; Grober et al., 1980; Zurif et al., 1974) was challenged. In these studies, aphasic patients were required to make speeded lexical decisions to target words (e.g., Blumstein, Milberg, \& Shrier, 1982; Chenery et al., 1990; Hagoort, 1993; Milberg \& Blumstein, 1981; Milberg et al., 1987; Ostrin \& Tyler, 1993). In a lexical decision task subjects have to decide as quickly as possible whether a letter string or a sound sequence is a word or not. It has been shown that neurologically unimpaired subjects are faster to make lexical decisions to words that are preceded by a semantically or associatively related context than to words preceded by an unrelated context (e.g., Balota \& Chumbley, 1984; de Groot, 1984; Neely, 1977, 1991). In the priming studies that tested Wernicke's aphasics (e.g., Blumstein et al., 1982; Friedman, Glosser, \& Diamond, 1988; Hagoort, 1993; Milberg \& Blumstein, 1981; Milberg et al., 1987), these patients consistently showed semantic facilitation. Importantly, they showed this effect even though earlier research had established that Wernicke's aphasics are severely impaired on explicit semantic judgment tasks (e.g., Goodglass \& Baker, 1976; Grober et al., 1980; Zurif et al., 1974). Apparently, the lexical-semantic impairments of Wernicke's aphasics are most evident when they are asked to consciously elaborate on aspects of activated word meanings (Graf \& Mandler, 1984; Hagoort, 1993). When lexical-semantic processing is assessed more implicitly, as in the priming studies with a lexical decision task, these patients do not show an impairment. This suggests that lexical-semantic knowledge might be largely preserved, and that these patients have a deficit in either accessing or exploiting this information under particular circumstances.

In general, the inter-task variations that have been observed for both Broca's and Wernicke's aphasics are difficult to reconcile with the idea that all aphasic comprehension problems are caused by a loss of linguistic information. Instead, it seems more likely that the aphasic deficits in some of these patients are related to an impairment at the level of the real-time processes that act upon linguistic information. 
One of the key questions within a processing impairment account of comprehension deficits in aphasic patients is the level at which this processing impairment manifests itself. Two proposals have recently been put forward. One is that the time course and/or activational dynamics of lexical access are affected in certain types of aphasic comprehenders, usually referred to as Broca's aphasics (e.g., Baum, 1989; Milberg et al., 1987; Milberg et al., 1995; Swinney et al., 1989). An alternative proposal suggests that automatic lexical access might be largely intact, but that problems arise at the postlexical level of lexical integration (e.g., Hagoort, 1990; Tyler et al., 1995).

The claim of impaired lexical access has been derived from two types of studies. One is a series of word priming experiments, in which Broca's aphasics sometimes failed to show the normal effect of shorter lexical decision latencies for targets preceded by words that are related in meaning compared to targets preceded by unrelated primes (Milberg \& Blumstein, 1981; Milberg et al., 1987). However, the support for this claim based on word priming studies is not decisive, for two reasons. First, in most of the semantic priming studies, Broca's aphasics did show an effect of priming (Blumstein et al., 1982; Hagoort, 1993; Katz, 1988; Milberg et al., 1995; Ostrin \& Tyler, 1993). Second, in order to be able to make claims about automatic access in priming studies, the SOA (Stimulus Onset Asynchrony) between prime and target has to be within certain limits. There is convincing evidence from priming studies in normal subjects that semantic facilitation at long SOAs cannot be attributed to automatic lexical activation processes alone, and in fact, should mostly be attributed to controlled processes (e.g., Balota \& Chumbley, 1984; de Groot, 1984; Neely, $1977,1991)$. It has been argued that some of these controlled processes share important characteristics with lexical integration in natural language comprehension (Hagoort, 1990). Importantly, only those studies that used a relatively long SOA failed to observe a semantic priming effect for Broca's aphasics. Therefore, the overall picture that emerges from the priming studies in Broca's aphasics seems to be more compatible with the idea that these patients have an impairment in lexical integration processes, rather than lexical access deficits.

A second type of evidence that has been used to support the impaired access account for Broca's aphasics is the resolution of lexical ambiguity on the basis of sentential-semantic context information. Swinney et al. (1989) found that Broca's aphasics, in contrast to normal control subjects and Wernicke's aphasics, were only able to select the most frequent meaning of an ambiguous word, even if the preceding sentence context biased the alternative, infrequent meaning. They concluded from these data that Broca's aphasics fail to exhaustively access lexical information. However, in a series of studies on the resolution of lexical ambiguities in sentence contexts, Hagoort (1990) obtained evidence for multiple access in Broca's aphasics. That is, they accessed both frequent and infrequent meanings of ambiguous words. Since, in contrast to the Swinney et al. (1989) study, in these studies the interval between sentence-final ambiguity and target word was varied, Hagoort (1990) could show that whereas the Broca's aphasics were able to access both meanings, they were delayed in using the context information to select the meaning that was the appropriate one given the sentence context. This suggests a delay in the integration of lexical information rather than in accessing this information.

In sum, it seems unlikely that aphasic comprehension deficits result from an impairment in automatically accessing lexical information. Instead, language comprehension deficits in aphasia might result from an impairment in the integration of lexical information into a higher order representation of the preceding context, as indicated by the results of the Hagoort (1990) study described above. As has been argued at length by Tyler et al. (1995), the bulk of the current evidence claimed to support the automatic access hypothesis can be readily interpreted in terms of an integration deficit, whereas other results (e.g., Hagoort, 1990; Hagoort et al., 1996; Tyler \& Ostrin, 1994; Tyler et al., 1995) are more compatible with an impairment at the level of lexical integration. This latter possibility is further tested in this study.

\section{The Present Study}

The present study investigates the possibility of a lexical integration impairment in aphasic patients by measuring ERPs. Since comprehension deficits occur in all of the aphasic patients that we tested, we were especially interested to relate their ERP effects to their scores on a comprehension subtest of a standardized aphasia test battery, independent of their syndrome classification (Broca's or Wernicke's aphasia). In particular, the $\mathbf{N 4 0 0}$ was used to test whether the severity of the aphasic comprehension deficit interacted with the ability to rapidly integrate lexical information into the preceding sentence context. This was done by presenting subjects with sentences that either ended normally, as for example in: "The children like to play in the garden," or with semantically anomalous words, as for example in: "The girl dropped the candy on the sky." The task of the subjects was to listen attentively to these sentences, with the understanding that sometimes a question about the content of the sentence would be asked. In accordance with results in the literature (e.g., Kutas \& Hillyard, 1980; Holcomb \& Neville, 1991; Gunter et al., 1992), an N400 congruity effect was expected for the neurologically unimpaired subjects. This means that the amplitude of the N400 to sentence-final congruent words ("garden" in the example) will be reduced when compared to the amplitude of the $\mathrm{N} 400$ to sentence-final anomalous words ("sky" in the example). This results from the fact that the meaning of an anomalous word does not match the semantic specifications of the preceding sentence 
context, which makes the integration of this word difficult. If comprehension deficits in aphasia affect the rate at which lexical information is integrated into the higher order representation of the preceding sentence context, then this will affect the word-by-word integration of lexical information (including word meaning) into the overall sentence representation. This presumably holds for most words in the sentence, including the sentence-final words. Therefore, a delay of the N400 congruity effect is expected in these patients. To the extent to which such a delay reduces the efficiency of lexical integration, an amplitude reduction of the N400 effect might be expected. Finally, it might be the case that the severity of the comprehension deficit interacts with the N400 congruity effect, which means that the largest deviation from the normal N400 effect is expected for those patients with the most severe comprehension deficits.

In order to be able to reliably ascribe possible changes in amplitude and/or latency of the N400 effect to the aphasic language deficit, a number of control measures were taken. First, to control for nonspecific effects of both aging and brain damage on the N400, a group of normal age-matched controls and a group of nonaphasic patients with a lesion in the right hemisphere were tested. Second, in addition to the N400 paradigm, the different subject groups were also tested with nonlinguistic stimuli. For this control study we used the classical auditory oddball paradigm, in which subjects were presented with a series of high and low tones. The task of the subjects was to count the infrequent (rare) low tones (oddballs) and to ignore the frequent high tones (standards). It has been shown that neurologically unimpaired subjects have a larger positive waveform to oddballs than to standard tones (the P300 effect). Comparing the pattern of results of this control study to the pattern of results of the language study for the different subject groups will help to determine the extent to which possible changes in the $\mathrm{N} 400$ effect in aphasic patients can be dissociated from the effects of brain damage on cognitive ERP-components in general. The possible changes in the N400 effects can then be reliably related to the specific comprehension impairments in these patients.

\section{RESULTS}

First, the results for the age-matched normal controls, the right hemisphere lesion controls (RH-controls), and the aphasic patients were analyzed separately. In addition, the data of each patient group were compared with the data of the normal controls in ANOVAs with subject group as the additional factor. Aphasic patient data were analyzed with the patients grouped on the basis of their scores on the comprehension subtest of the AAT (see Method section), regardless of the clinical syndrome (Broca's aphasia, Wernicke's aphasia), with 7 subjects in each group ${ }^{1}$ (see Table 1 for information on individual patients). Low comprehenders (LO) had moderate to severe comprehension deficits according to their comprehension scores on the comprehension subtest of the AAT. High comprehenders (HI) had light to very mild comprehension deficits, according to their scores on this subtest.

\section{Analysis of N400 Effects}

Prior to off-line averaging, all single-trial waveforms were screened for electrode drifting, amplifier blocking, muscle artifacts, eye movements and blinks. This was done over an epoch of $1750 \mathrm{~ms}$, starting $250 \mathrm{~ms}$ before the onset of the sentence-final word. Trials containing artifacts were rejected. However, for subjects with a substantial number of blinks, those single trials that were without amplifier blocking were corrected with a procedure described by Gratton, Coles, and Donchin (1983), and included in the relevant ERP averages. After artifact rejection, the overall rejection rate was $6 \%$ for the normal controls, $26 \%$ for the high comprehenders, $28 \%$ for the low comprehenders, and $25 \%$ for the right hemisphere lesion controls.

Average waveforms were computed for each subject over the anomalous and the congruent sentence-final words. Statistical analyses were done on the amplitude of the N400, using repeated measures analysis of variance (ANOVA), with the within-subject factors of Congruity of sentence-final words (Congruent, Anomalous), and Electrode Site ( $\mathrm{Fz}, \mathrm{Cz}, \mathrm{Pz}, \mathrm{AL}, \mathrm{PL}, \mathrm{AR}, \mathrm{PR})$. In addition, the N400 amplitude of each patient group was compared to that of the normal controls, with Group of Subjects as the additional factor. The degrees of freedom for the F-tests were adjusted using the procedure described by Greenhouse and Geisser (1959; see Winer, 1971), to compensate for inhomogeneous variances and covariances across treatment levels. The adjusted degrees of freedom and $p$-values will be presented.

Separate ANOVAs were done on the mean amplitude of the N400 in three time windows: The $300-700 \mathrm{~ms}$, the 300-500 ms, and the 500-700 ms epochs after the onset of the sentence-final words, relative to a $100 \mathrm{~ms}$ baseline preceding the sentence-final words. These epochs were determined after visual inspection of the waveforms and based on prior literature (Hagoort et al., 1996; Gunter et al., 1992). The overall epoch of 300-700 ms was divided into an early (300-500 ms) and a late $(500-700 \mathrm{~ms})$ window to help quantify an apparent latency shift of the N400 effect in the low comprehenders.

\section{Normal Controls}

Figure 1 shows the average waveforms of the sentencefinal words for the elderly normal controls. As can be seen in this figure, no clear $\mathrm{N} 1$ or P2 components show up in the ERPs to the sentence-final words. These com- 
Figure 1. Elderly Normal Controls $(N=12)$, Sentence-Final Word. Grand average ERPs from the normal controls subjects $(n=12)$ to the anomalous (solid line) and congruent (dotted line) sentence-final words.

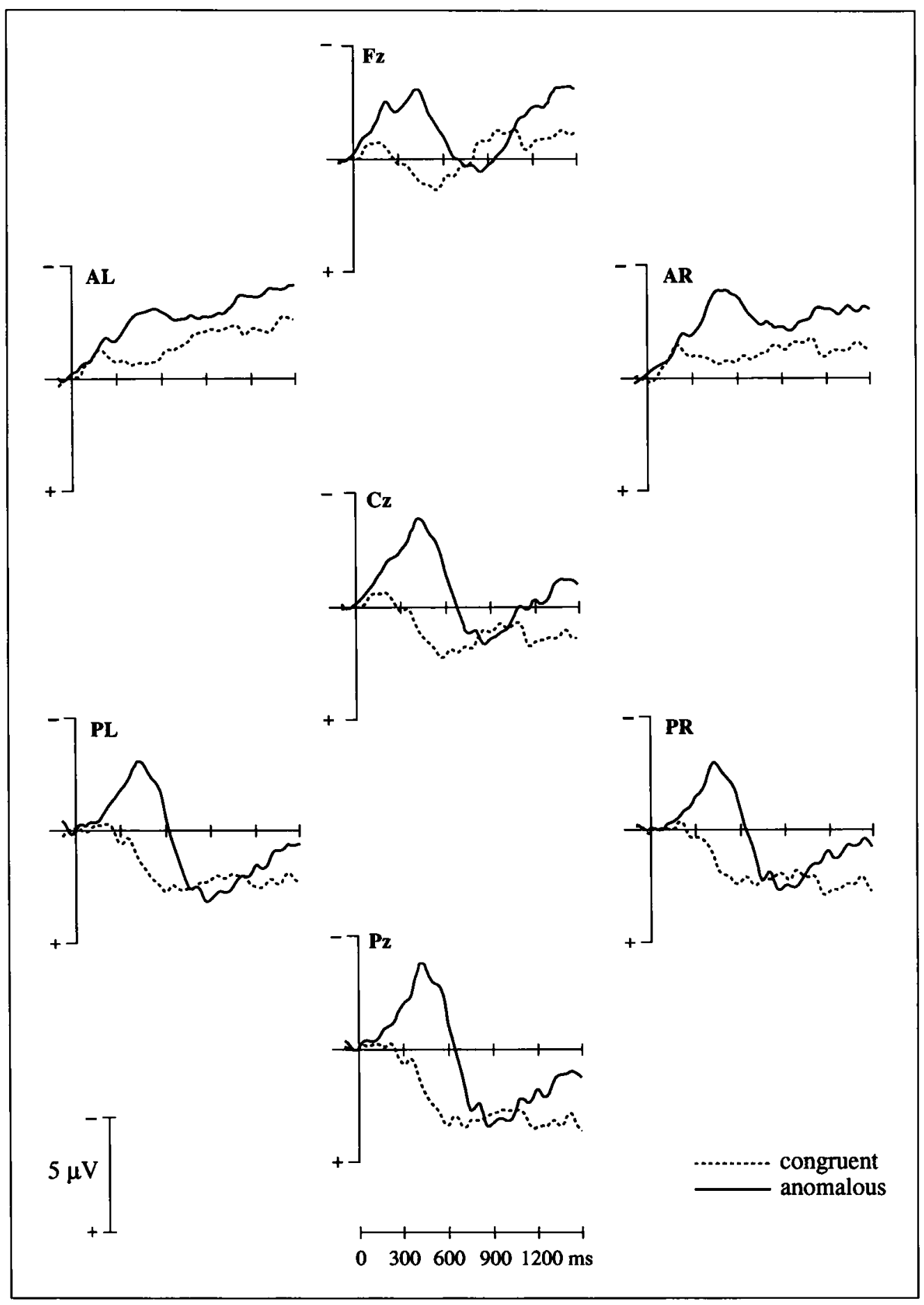

ponents were attenuated because the sentence-final words were embedded in the continuous speech stream, with no clear physical separation between the end of the penultimate and the beginning of the sentence-final word. ${ }^{2}$ The waveforms in the anomalous conditions are characterized by a sizeable negative deflection (the N400), followed by a positive going deflection over the midline and lateral posterior sites. In the congruent condition, the waveforms tend to show a positive deflection. The difference between conditions, the $\mathbf{N} 400$ Congruity effect, shows a centroparietal distribution (see Holcomb
\& Neville, 1991 for similar results in continuous speech) and is slightly smaller over the anterior left scalp site than over the anterior right scalp site.

The N400 Congruity effect $(-3.09 \mu \mathrm{V})$ was highly significant in the 300-700 ms epoch after sentence-final word onset $(F(1,11)=30.89, M S e=12.97, p<0.0003)$. Both the ANOVAs on the early (300-500 ms: $-3.27 \mu \mathrm{V})$ and late $(500-700 \mathrm{~ms}:-2.91 \mu \mathrm{V})$ temporal windows yielded similar results (early: $F(1,11)=31.18, M S e=$ 14.40, $p<0.0003$; late: $F(1,11)=22.48, M S e=15.79, p$ $<0.0007$ ). 
Figure 2. Right Hemisphere Patients $(N=6)$, SentenceFinal Word. Grand average ERPs from the right hemisphere patients $(n=6)$ to the anomalous (solid line) and congruent (dotted line) sentence-final words.

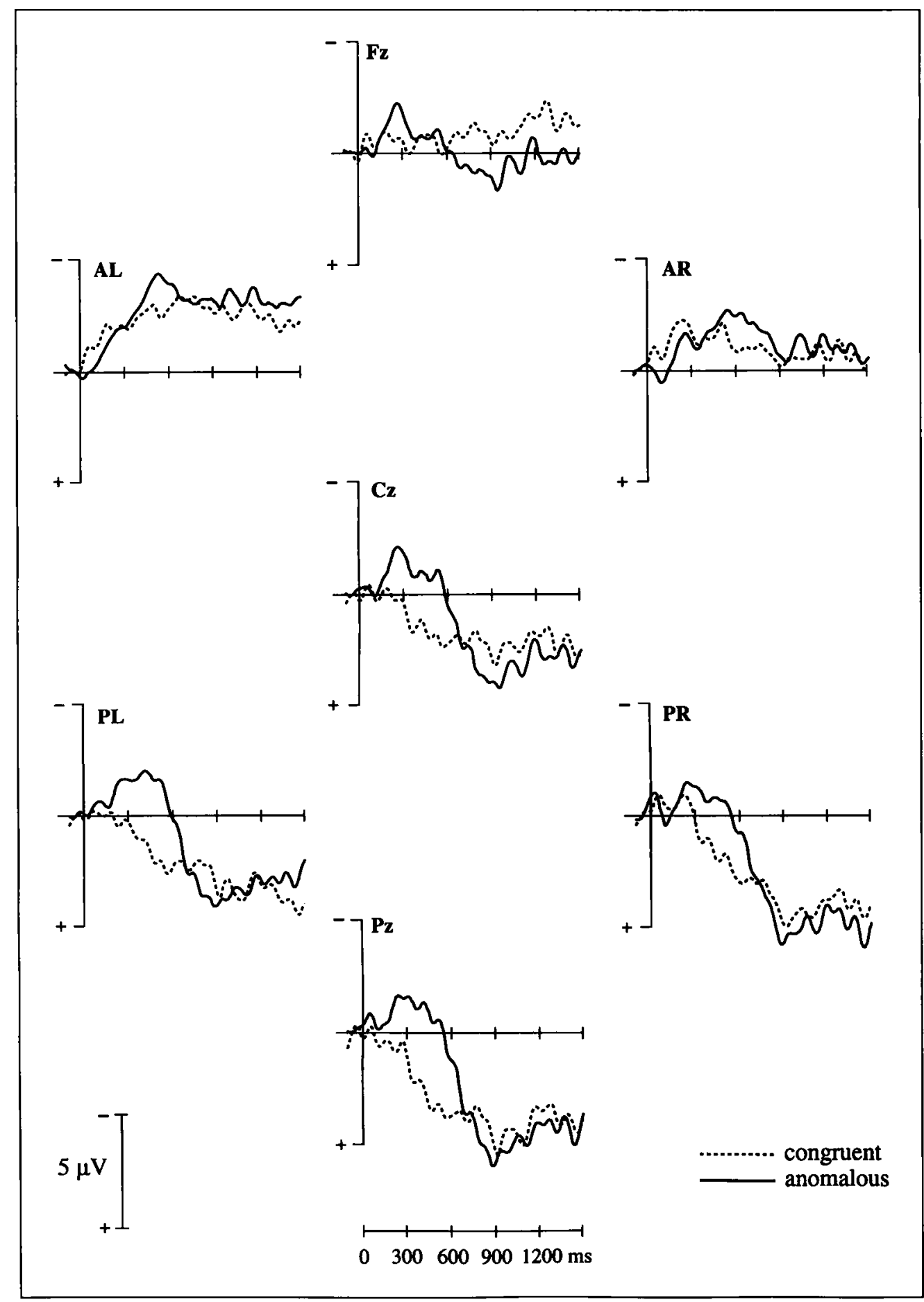

In sum, the normal controls showed the expected N400 effect of congruity. The effect had a centroparietal distribution, ${ }^{3}$ and was slightly larger $(-0.36 \mu \mathrm{V})$ in the 300-500 ms epoch than in the 500-700 ms epoch.

\section{Right Hemispbere Patients}

Figure 2 presents the average waveforms for the group of RH-controls. Their N400 effect shows a centroparietal distribution. But, in contrast to the normal controls, the effect is slightly smaller over the posterior right scalp site than over the posterior left scalp site, and relative to the normal controls, it is reduced at anterior sites.

The ANOVA in the 300-700 ms epoch yielded a significant $\mathrm{N} 400$ effect of Congruity $(-1.56 \mu \mathrm{V})$ for the right hemisphere patients $(F(1,5)=7.78, M S e=6.56, p$ $<0.04)$. An additional ANOVA comparing the right hemisphere patients with the normal controls revealed no significant interaction between Congruity and Group of Subjects $(F(1,16)=2.99$, MSe $=10.97, p<0.11)$. In other words, even though a reduction of the $\mathrm{N} 400$ effect can be seen for the right hemisphere patients relative to the 
normal controls in Figures 1 and 2, the overall pattern of results was statistically not significantly different between these groups.

As in the $300-700 \mathrm{~ms}$ epoch analysis, a significant $\mathrm{N} 400$ Congruity effect $(-1.76 \mu \mathrm{V})$ was obtained in the analysis over the early $(300-500 \mathrm{~ms})$ epoch $(F(1,5)=$ 9.10, $M S e=7.15, p<0.03$ ). Comparison with the normal controls showed no Congruity by Group of Subjects interaction $(F(1,16)=2.63, M S e=12.13, p<0.13)$. In the late epoch (500-700 ms), the $\mathrm{N} 400$ Congruity effect $(-1.36 \mu \mathrm{V})$ for the right hemisphere patients was only marginally significant $(F(1,5)=4.25, M S e=9.08, p=$ 0.09). When compared with the normal controls, there was again no Congruity by Group of Subjects interaction $(F(1,16)=2.46, M S e=13.69, p=0.14)$.

In sum, nonaphasic patients with a right hemisphere lesion showed a clear $\mathrm{N} 400$ Congruity effect. The size of the effect was reduced relative to the normal controls, especially over anterior sites (see Figures 1 and 2). However, for none of the analysis epochs does this difference become statistically significant. Finally, as was the case for the normal controls, when comparing the early and late windows the difference between conditions was larger $(-0.40 \mu \mathrm{V})$ in the $300-500 \mathrm{~ms}$ than in the $500-700$ ms window.

\section{High Comprebenders}

Figure 3 presents the average waveforms for the high comprehenders. A comparison of the morphology of the waveforms for the normal controls and the high comprehenders shows that the negative deflection in the anomalous condition is less prominent for the high comprehenders than for the normal controls and that the positive deflection in the congruent condition is more prominent for the high comprehenders than for the normal controls. However, most important, the ERPdifference between the congruent and the anomalous condition (the Congruity effect) is comparable in size and topographical distribution for normal controls and high comprehenders (see also Fig. 6).

The ANOVA yielded a significant effect of Congruity $(-2.23 \mu \mathrm{V})$ for the $300-700 \mathrm{~ms}$ epoch $(F(1,6)=8.44$, $M S e=14.44, p<0.03$ ). The ANOVA with Group of Subjects as the additional factor did not result in a significant Congruity by Group of Subjects interaction $(F<1)$. A significant N400 effect of Congruity $(-2.50 \mu \mathrm{V})$ was also found in the early epoch $(F(1,6)=11.40, M S e$ $=13.46, p<0.02)$. In the late epoch, the Congruity effect $(-1.96 \mu \mathrm{V})$ was marginally significant $(F(1,6)=5.43$, MSe $=17.28, p<0.06$ ). Importantly, however, no Congruity by Group of Subjects interactions were found for either measurement epoch (early: $F<1$; late: $F<1$ ).

In sum, the aphasic patients with mild comprehension deficits were clearly sensitive to the congruity of sentence-final words. This was evident from their $\mathrm{N400}$ effect that, although slightly smaller, was statistically indistinguishable from the normal controls. Just as for the normal controls, the effect was larger $(-0.54 \mu \mathrm{V})$ in the early epoch than in the late epoch.

\section{Low Comprebenders}

Figure 4 presents the average waveforms for the low comprehenders. The overall morphology of the waveforms for the low comprehenders is comparable to that of the normal controls: A negative deflection to the sentence-final words in the anomalous condition and a positive going deflection in the waveforms in the congruent condition at centroparietal sites. However, compared to the normal controls the effect is reduced, especially at centroparietal sites, and it appears to have a later onset (see also Fig. 6).

The ANOVA for the overall $300-700 \mathrm{~ms}$ latency window showed a significant effect $(-1.87 \mu \mathrm{V})$ of Congruity $(F(1,6)=14.51$, MSe $=5.93, p<0.009)$. The effects in the early 300-500 ms epoch $(-1.46 \mu \mathrm{V})$ and the late 500-700 ms epoch $(-2.29 \mu \mathrm{V})$ were also significant (early: $F(1,6)=8.31, M S e=6.24, p<0.03$; late: $F(1,6)$ $=10.40$, MSe $=12.37, p<0.02$ ).

When comparing the low comprehenders with the normal controls, no significant Congruity by Group of Subjects interactions were found for the overall 300-700 ms window $(F(1,17)=2.18, M S e=10.48, p=0.16)$ and for the late $500-700 \mathrm{~ms}$ window $(F<1)$. However, in the early 300-500 ms window this interaction was significant $(F(1,17)=4.42, M S e=11.52, p=0.05)$. This was due to a delay of the $\mathrm{N400}$ effect in the low comprehenders relative to the normal controls. In contrast to the normal controls and the other patient groups, the $\mathrm{N400}$ Congruity effect in the low comprehenders reached its maximum amplitude in the late measurement epoch, where it was $-0.83 \mu \mathrm{V}$ larger than in the early epoch. This difference between the low comprehenders and the other subject groups is illustrated in Figures 5 and 6.

In Figure 5, the size of the Congruity effects (in mean amplitude) in the early and late epochs is shown for the normal controls and the three patient groups. As can be seen in Figure 5, the low comprehenders clearly showed an increase in the size of the $\mathrm{N} 400$ Congruity effect in the late window relative to the early window, while all the other groups showed a decrease of the N400 effect in the late relative to the early window.

Figure 6 presents an overlay of the difference waveforms for the centroparietal electrode sites for the four subject groups. This figure shows a clear shift in the latency of the $\mathrm{N} 400$ effect in the low comprehenders, which peaks about 100 ms later in the low comprehenders than in the other subject groups. For the low comprehenders, the $\mathrm{N} 400$ effect reached its average maximum peak averaged over the four centroparietal leads at $580 \mathrm{~ms}$, which was substantially later than for 
Figure 3. Aphasic Patients, High Comprehenders $(N=7)$, Sentence-Final Word. Grand average ERPs from the high com prehenders $(n=7)$ to the congruent (dotted line) sentence-final words. anomalous (solid line) and

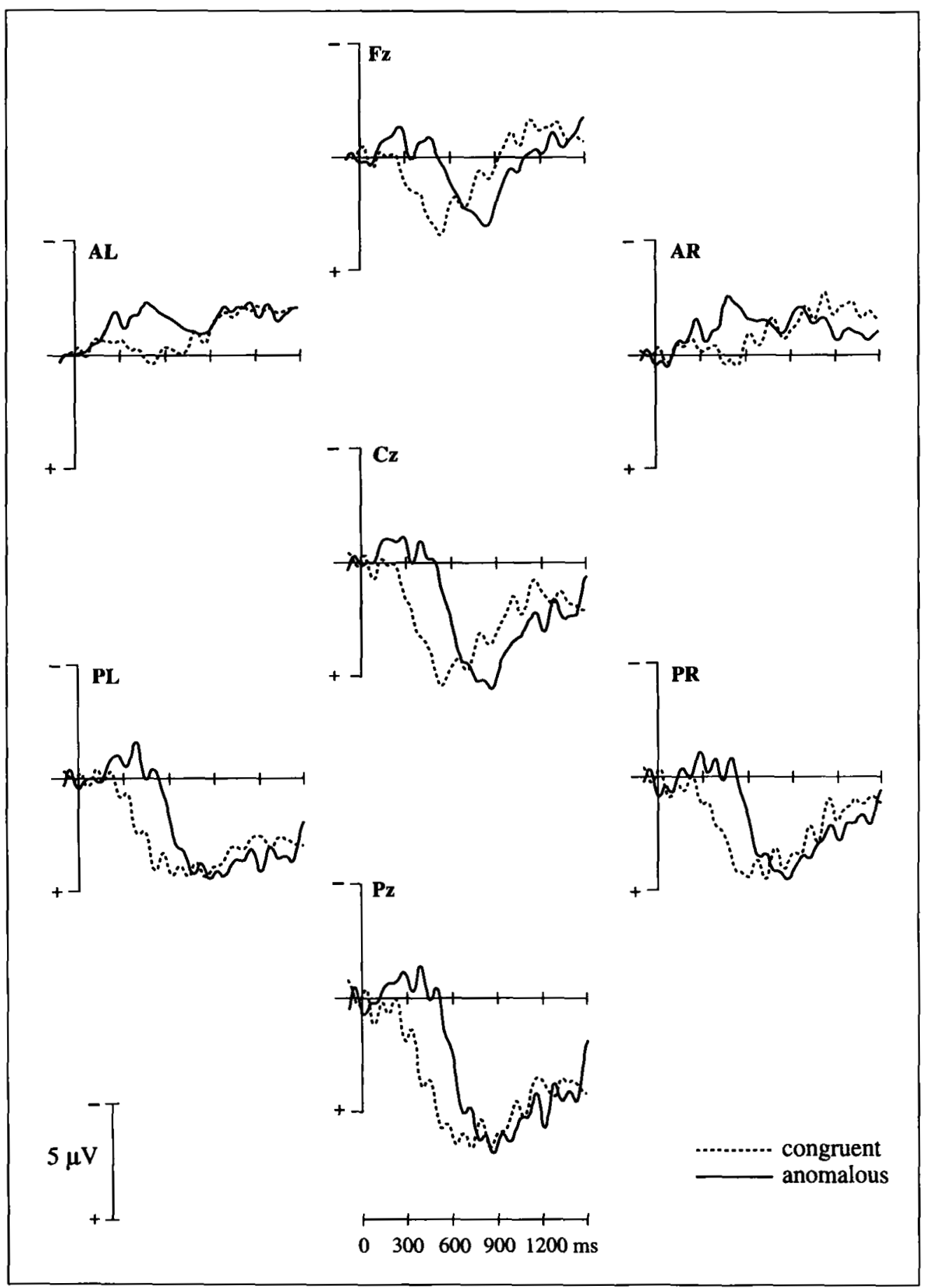

the normal controls ( $483 \mathrm{~ms}$ ), the right hemisphere controls ( $478 \mathrm{~ms})$, and the high comprehenders ( $484 \mathrm{~ms}$ ).

In addition to the separate ANOVAs in the early (300$500 \mathrm{~ms}$ ) and the late (500-700 ms) latency windows, we subsequently performed two analyses to further help quantify the latency shift of the N400 effect that was observed for the low comprehenders. First, we did an ANOVA on the N400 effect (anomalous-congruent) including both temporal windows, in order to test whether there was a significant interaction between
Group of Subjects and Latency Window. This interaction was not significant when comparing the normal controls with either the right hemisphere lesion controls $(F<1)$ or with the high comprehenders $(F<1)$. For the comparison between the normal controls and the low comprehenders the Group of Subjects by Latency Window interaction was in the right direction, but not statistically significant $(F(1,17)=2.16, M S e=10.30, p=0.16)$. It might be the case that this interaction failed to reach significance because of the small power of the between 
Figure 4. Aphasic Patients, Low Comprehenders $(N=7)$, Sentence-Final Word. Grand average ERPs from the low comprehenders $(n=7)$ to the anomalous (solid line) and congruent (dotted line) sentence-final words.

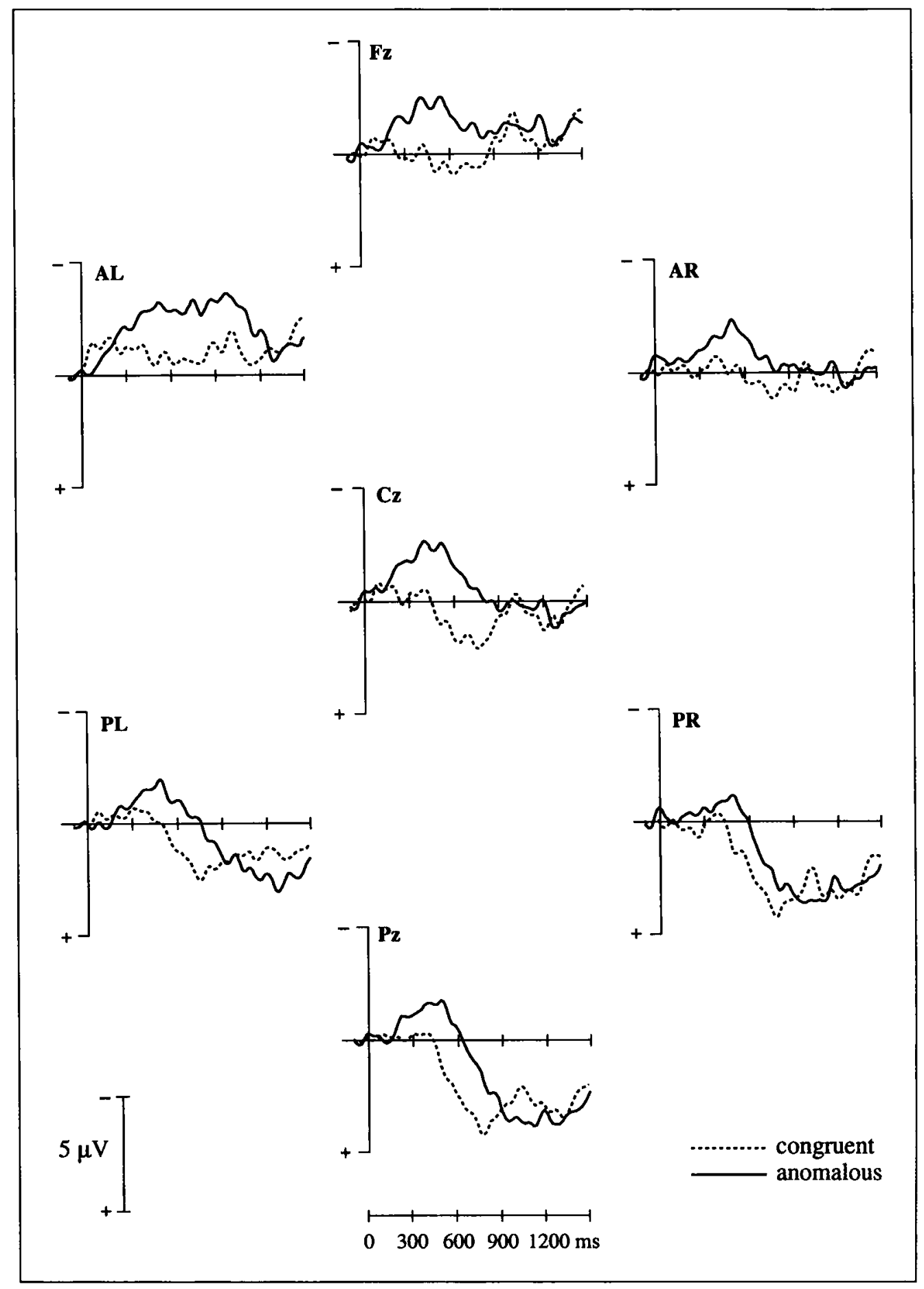

group comparison (only 7 low comprehenders). But because we did not find a significant difference here, we also approached the latency issue in a different way. Following Holcomb and Neville (1991), we determined the onset latencies of the $\mathrm{N} 400$ effect by statistical testing in 14 successive $50 \mathrm{~ms}$ windows (from 0-700 ms after the sentence-final word). This was done for each subject group separately. These ANOVAs showed that the earliest significant difference was at $200 \mathrm{~ms}$ for the normal controls $(F(1,11)=9.18, M S e=5.50, p<0.02)$, at $300 \mathrm{~ms}$ for the right hemisphere lesion controls
$(F(1,5)=17.21, M S e=3.81, p=0.009 ;$ but a marginally significant difference was already found at $250 \mathrm{~ms}$ : $F(1,5)=5.44, M S e=4.04, p=0.07)$, at $250 \mathrm{~ms}$ for the high comprehenders $(F(1,6)=8.81, M S e=16.66, p<$ 0.03), but only at $350 \mathrm{~ms}$ for the low comprehenders $(F(1,6)=6.74, M S e=6.56, p<0.05)$. The results from these additional analyses point in the same direction as the results from the separate ANOVAs in the early and the late latency windows, namely that the latency of the N400 effect for the low comprehenders clearly shifted in time compared to the normal controls. 
Figure 5. N400 Effect in Early and Late Epoch. Mean amplitude of the N400 effect for all the subject groups in the early ( $300-500 \mathrm{~ms})$ and late ( $500-700 \mathrm{~ms})$ epochs.

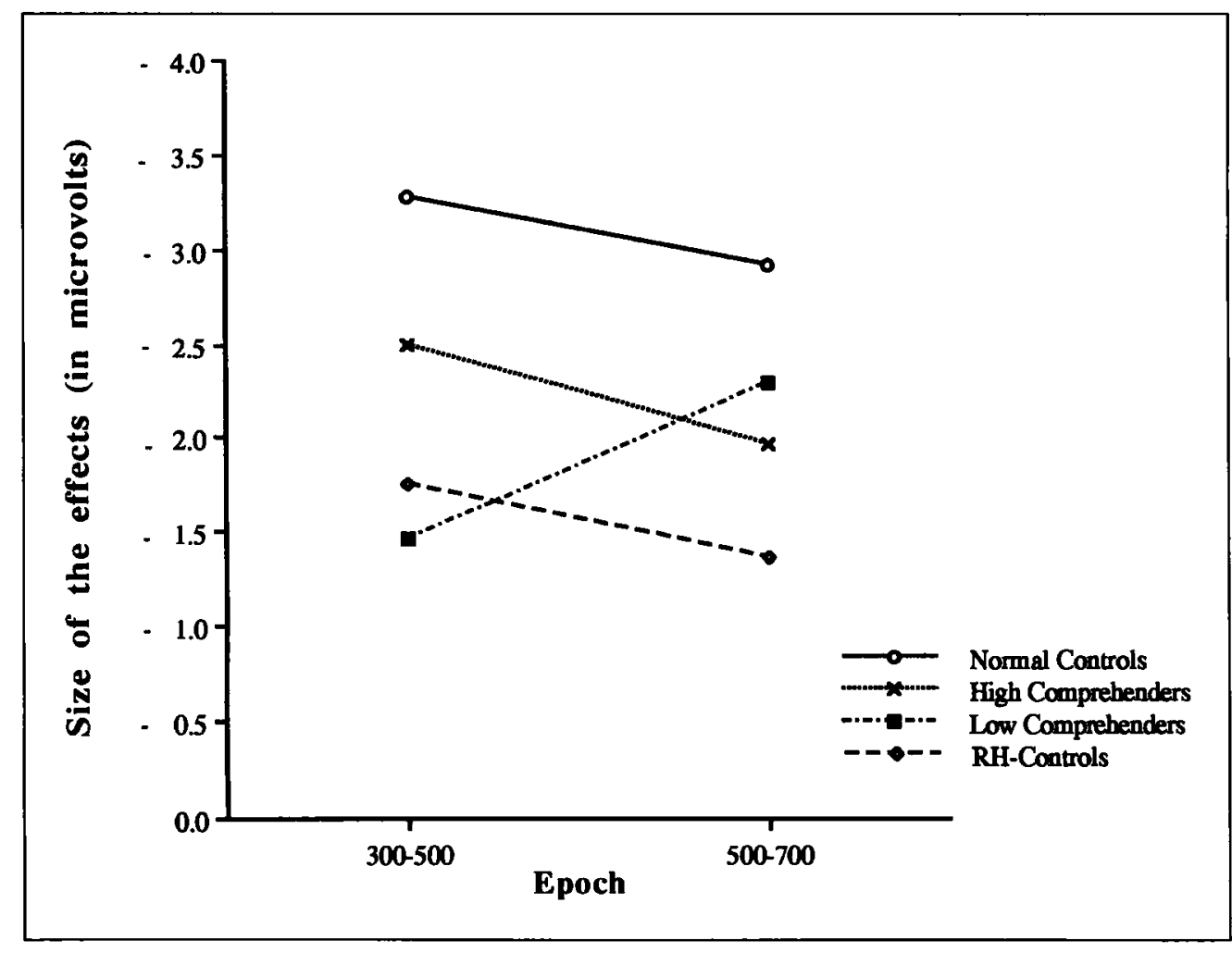

\section{Analysis of P300 Effects}

Artifact rejection and correction procedures were identical to the ones for the N400 data, except that for the P300 an epoch of $1000 \mathrm{~ms}$ was screened for artifacts, starting $150 \mathrm{~ms}$ before the onset of the stimulus. The overall rejection rate was $16 \%$ for the normal controls, $7 \%$ for the high comprehenders, $14 \%$ for the low comprehenders, and $17 \%$ for the right hemisphere lesion controls.

Average waveforms were computed for each subject for the frequent high tones (standards) and the rare low tones (oddballs). Repeated measures ANOVAs were done for each subject group separately on the mean amplitude of the P300 in the 250-500 ms epoch after stimulus onset, relative to a $150 \mathrm{~ms}$ prestimulus baseline. The factors that entered the analyses were: Subjects, Tone Probability (High vs Low), and Electrode Site (Fz, Cz, Pz, AL, PL, AR, PR). Next to the separate group analyses, the data for each patient group were compared to the data of the normal controls in analyses with Group of Subjects as an additional between-subject factor.

\section{Normal Controls}

The average waveforms for the group of normal controls are shown in Figure 7. This figure shows frontally distributed N1 and P2 components, and a large P300 component in the oddball condition with a characteristic centroparietal distribution. ${ }^{4}$ Statistical analysis yielded a highly significant P300 effect of Tone Probability (F(1, 11) $=50.84, M S e=17.66, p<0.0001$ ).
Right Hemispbere Patients

Figure 8 presents the average waveforms for the right hemisphere lesion control group. Overall, N1, P2, and P300 components are reduced relative to the normal controls, but the $\mathrm{N} 1$ and the $\mathrm{P} 2$ have retained their frontal distribution, and the P300 component has a normal centroparietal distribution. In contrast to the normal controls, the P300 effect is larger over the posterior left scalp site than over the posterior right scalp site. The P300 effect was only marginally significant $(F(1,5)=$ $4.29, M S e=29.02, p=0.09$ ). In order to determine whether the pattern of results for these brain damaged patients was comparable to that of the normal controls, a between group analysis was done, with Group of Subjects as an additional factor. Although the P300 effect was smaller in the right hemisphere patients than in the controls, the Group of Subjects by Tone Probability interaction was only marginally significant $(F(1,16)=3.16$, $M S e=21.21, p=0.09$ ).

\section{High Comprebenders}

Figure 9 presents the average waveforms for the high comprehenders. The high comprehenders also showed clear N1, P2, and P300 components in the waveforms. The N1 and the P2 had a normal frontal distribution, and the P300 effect had the typical centroparietal distribution. Relative to the normal controls, the size of the components was reduced, with the largest reduction at anterior left and posterior left electrode sites. The 
Figure 6. Difference Waveforms, Sentence-Final Word. Grand average difference waveforms (anomalous minus congruent) over centroparietal sites for the normal controls (thin solid line), the high comprehenders (dotted line), the low comprehenders (dashed line), and the right hemisphere patients (thick solid line).

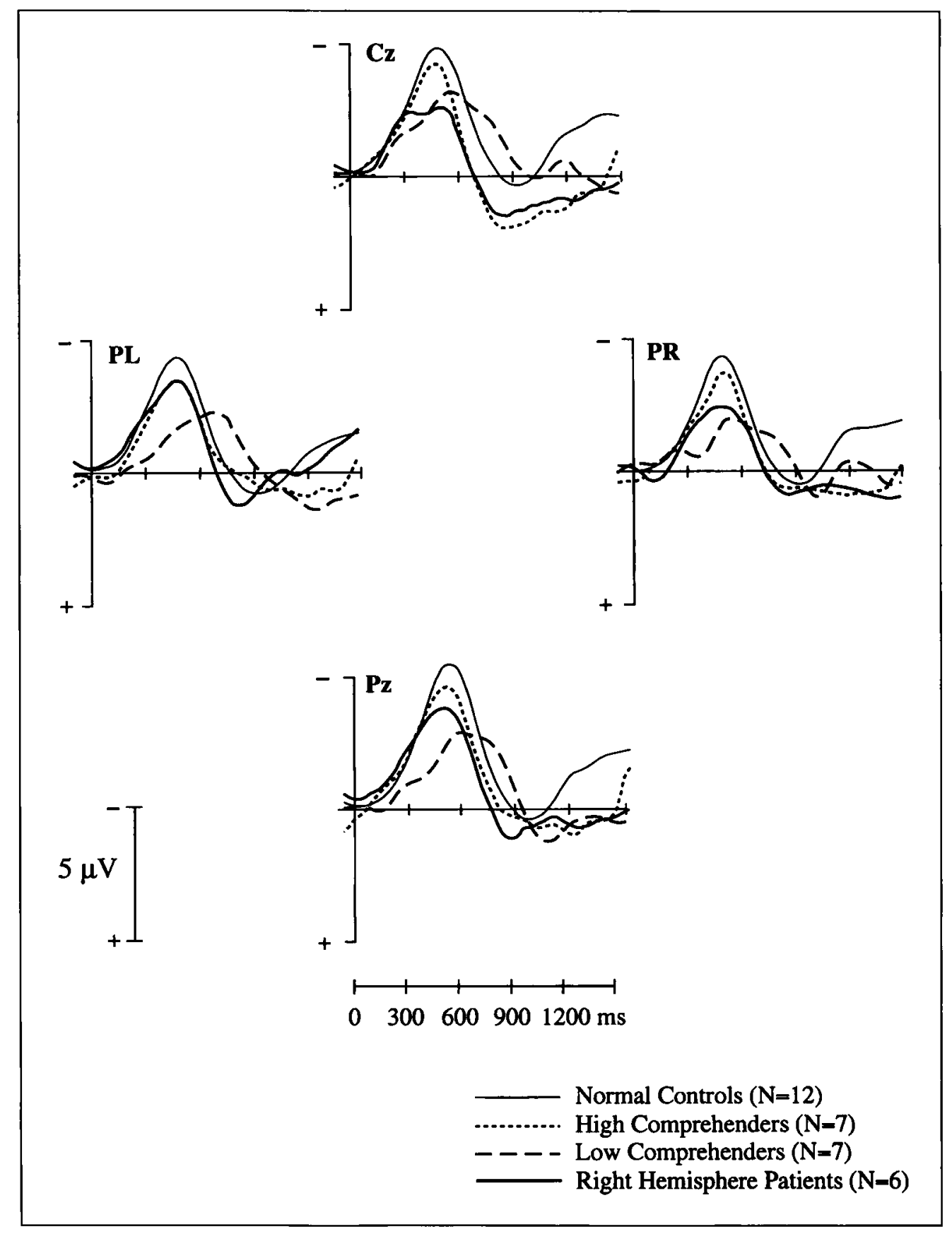

ANOVA yielded a significant $\mathrm{P} 300$ effect $(F(1,6)=17.24$, $M S e=24.06, p<0.007)$, that was comparable to that of the normal controls (Group of Subjects by Tone Probability: $F<1$ ).

\section{Low Comprebenders}

Figure 10 presents the average waveforms for the low comprehenders. As is seen in Figure 10, N1 and P2 components are clearly reduced, and the $\mathrm{P} 300$ component is absent in the waveforms for the low comprehenders. No significant $\mathrm{P} 300$ effect was obtained for these patients $(F<1)$. The results for this group clearly devi- ated from the normal controls, as was substantiated by a significant Group of Subjects by Tone Probability interaction $(F(1,17)=15.65$, MSe $=29.00, p<0.002)$.

Thus, the statistical analyses of the P300 data in the patients revealed that only the high comprehenders had a significant P300 effect. This effect was statistically indistinguishable from that of the normal controls even though it was slightly smaller in amplitude in these patients (see Fig. 7 vs Fig. 9). The P300 effect of the right hemisphere patients was only marginally significant, and there was a marginally significant reduction in the size of the effect in these patients relative to the normal controls. Finally, the low comprehenders did not show a 
Figure 7. Elderly Normal Controls $(\mathrm{N}=12)$, Tone Oddball Task. Grand average ERPs from the normal controls subjects $(n=12)$ to the frequent (dotted line) and the rare tones (solid line) in the oddball paradigm.

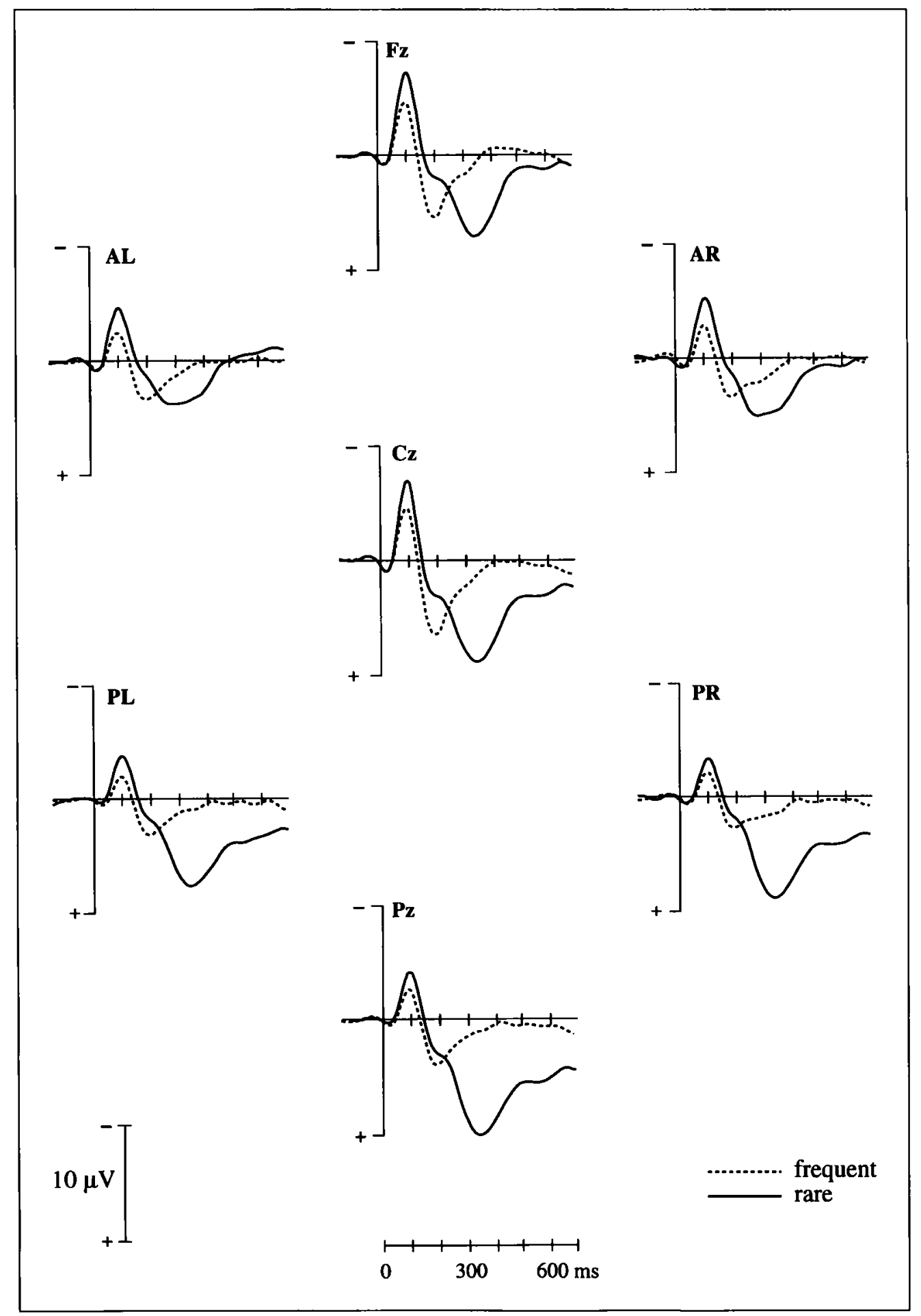

P300 effect at all. This, however, was partly due to individual subject differences (see below).

\section{Individual Subject Data}

Figures 11 and 12 present the mean amplitude over electrode $\mathrm{Cz}$ of the $\mathrm{N} 400$ effects for the sentence-final words in the 300-700 ms epoch, and the mean amplitude of the P300 effects in the tone oddball paradigm, for the individual subjects in the control groups (normal controls, right hemisphere lesion controls) and the aphasic patients, respectively. Electrode $\mathrm{Cz}$ was chosen because it is a representative site for the $\mathbf{N} 400$ effect.

As is clear from these figures, there is variation in the size of the N400 effect within all of the subject groups. However, eleven of the normal controls and five of the right hemisphere lesion controls showed an N400 effect (Fig. 11). Thirteen of the fourteen aphasic patients also 
Figure 8. Right Hemisphere Patients $(\mathrm{N}=6)$, Tone Oddball Task. Grand average ERPs from the right hemisphere patients $(n=6)$ to the frequent (dotted line) and the rare (solid line) in the oddball paradigm.

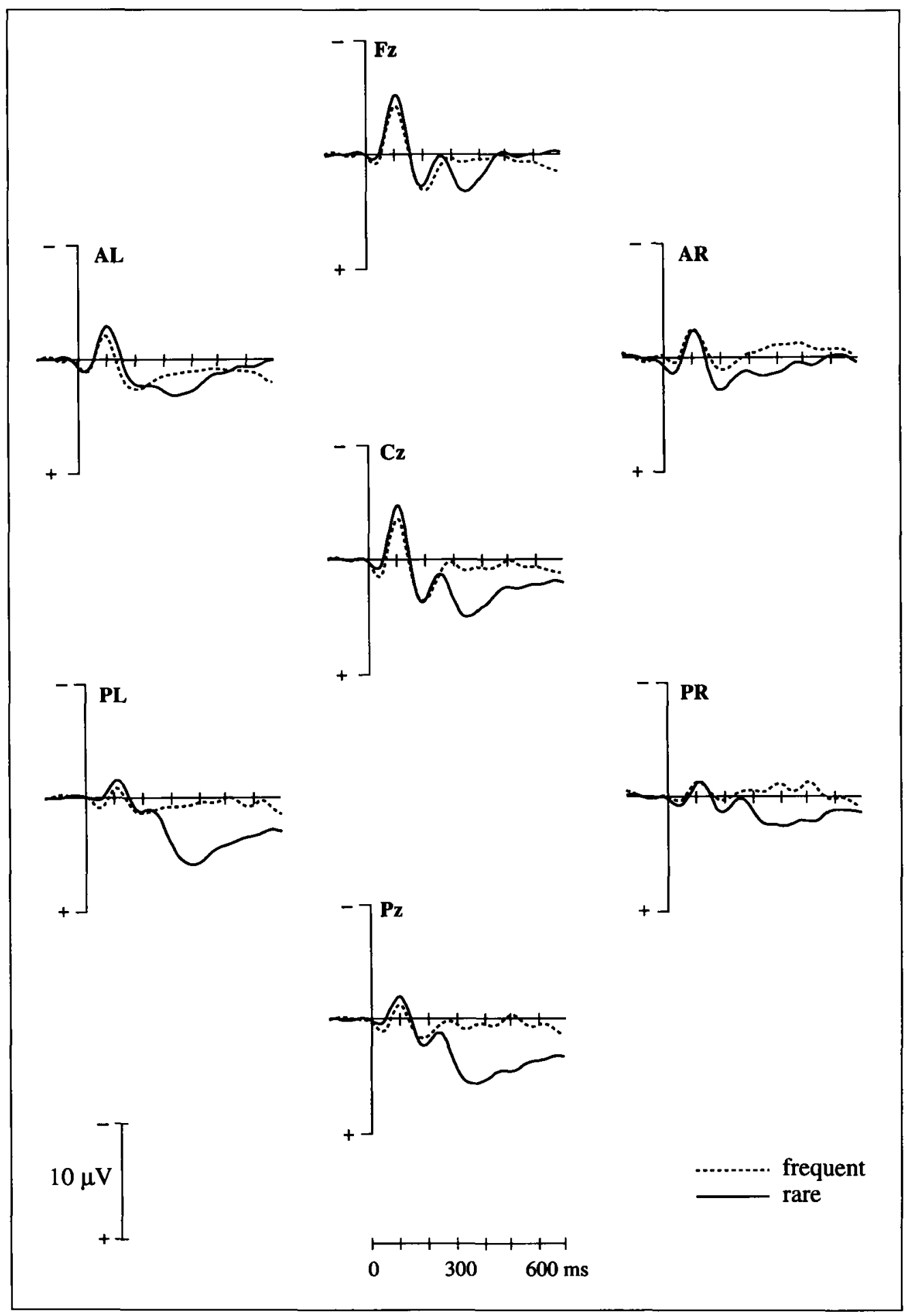

Eleven normal control subjects, five of the six right hemisphere lesion controls, and ten of the fourteen aphasic patients showed $P 300$ effects, which varied in size. One of the normal controls, one of the right hemisphere lesion controls, and four aphasic patients showed more negative waveforms to the rare low tones than to the frequent high tones. These abnormal oddball effects have been reported elsewhere (Hagoort et al., 1996) but are without adequate explanation.

Knight, Scabini, Woods, and Clayworth (1989) have 
Figure 9. Aphasic Patients, High Comprehenders $(N=7)$, Tone Oddball Task. Grand average ERPs from the high comprehenders $(n=7)$ to the frequent (dotted line) and the rare tones (solid line) in the oddball paradigm.

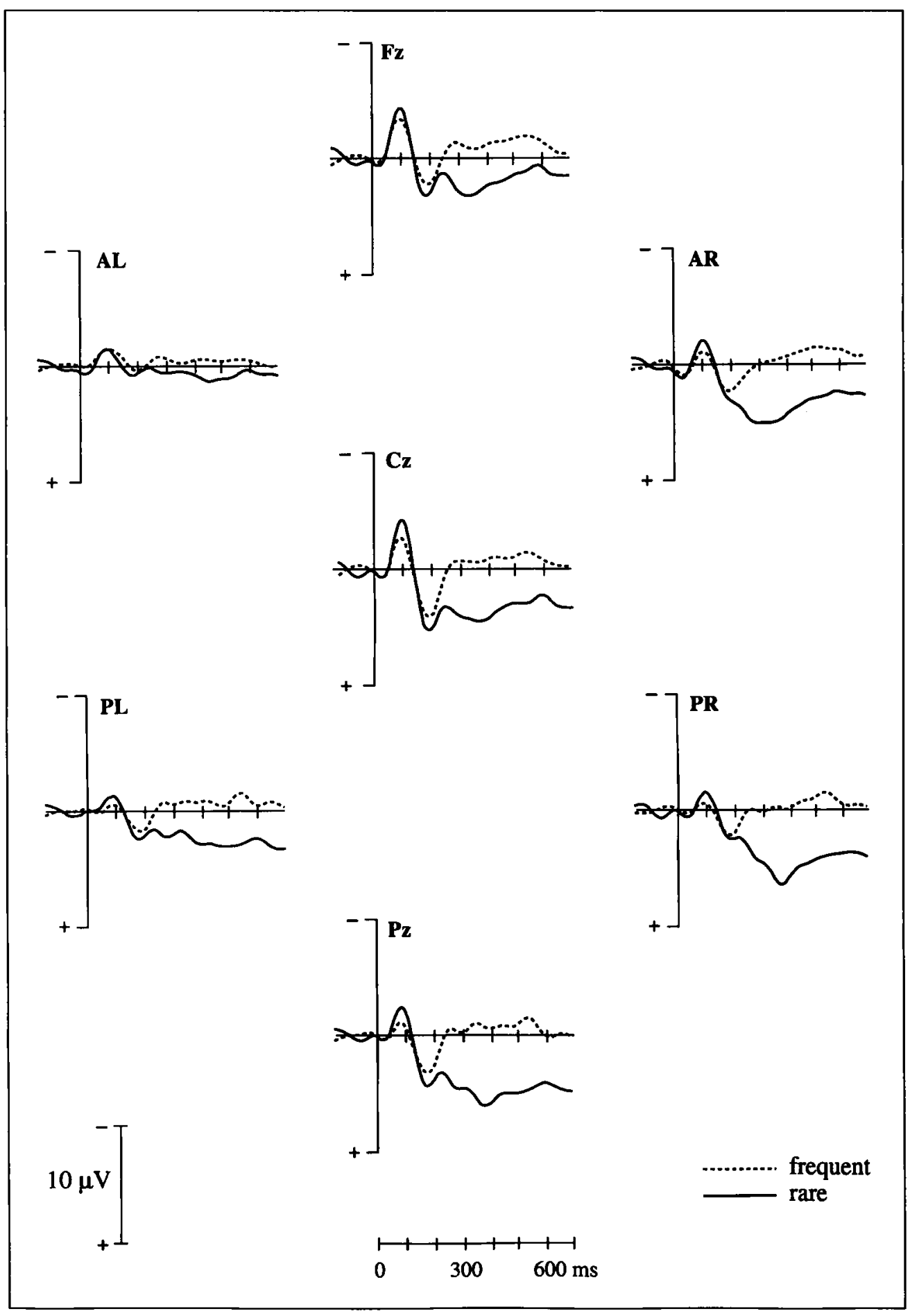

found that the temporal parietal junction is crucial in generating a normal P300 effect (more positive waveforms to rare targets than to frequent standards). However, that cannot fully explain the abnormal P300 effect that was found for some of the patients in the present study. Only two of the four aphasic patients that had an abnormal P300 effect had a lesion that included the temporal parietal junction, and there was no adequate CT information available on the right hemisphere patient that had an abnormal P300 effect. Since the oddball experiment only served as a control in the current study and was not designed to answer questions about neural generators of the $\mathrm{P} 300$, further consideration of these results with respect to the origins of the $\mathrm{P} 300$ is beyond the scope of the current study.

As in the Hagoort et al. (1996) study, the abnormal P300 effect did relate to the inability to count. Five of the aphasic patients were unable to count (patients 5,7, $10,12,14$ in Figure 12), and three of these patients had an abnormal $P 300$ effect (patients 10, 12, 14). The abnor- 
Figure 10. Aphasic Patients, Low Comprehenders $(\mathrm{N}=7)$, Tone Oddball Task. Grand average ERPs from the low comprehenders $(n=7)$ to the frequent (dotted line) and the rare tones (solid line) in the oddball paradigm.

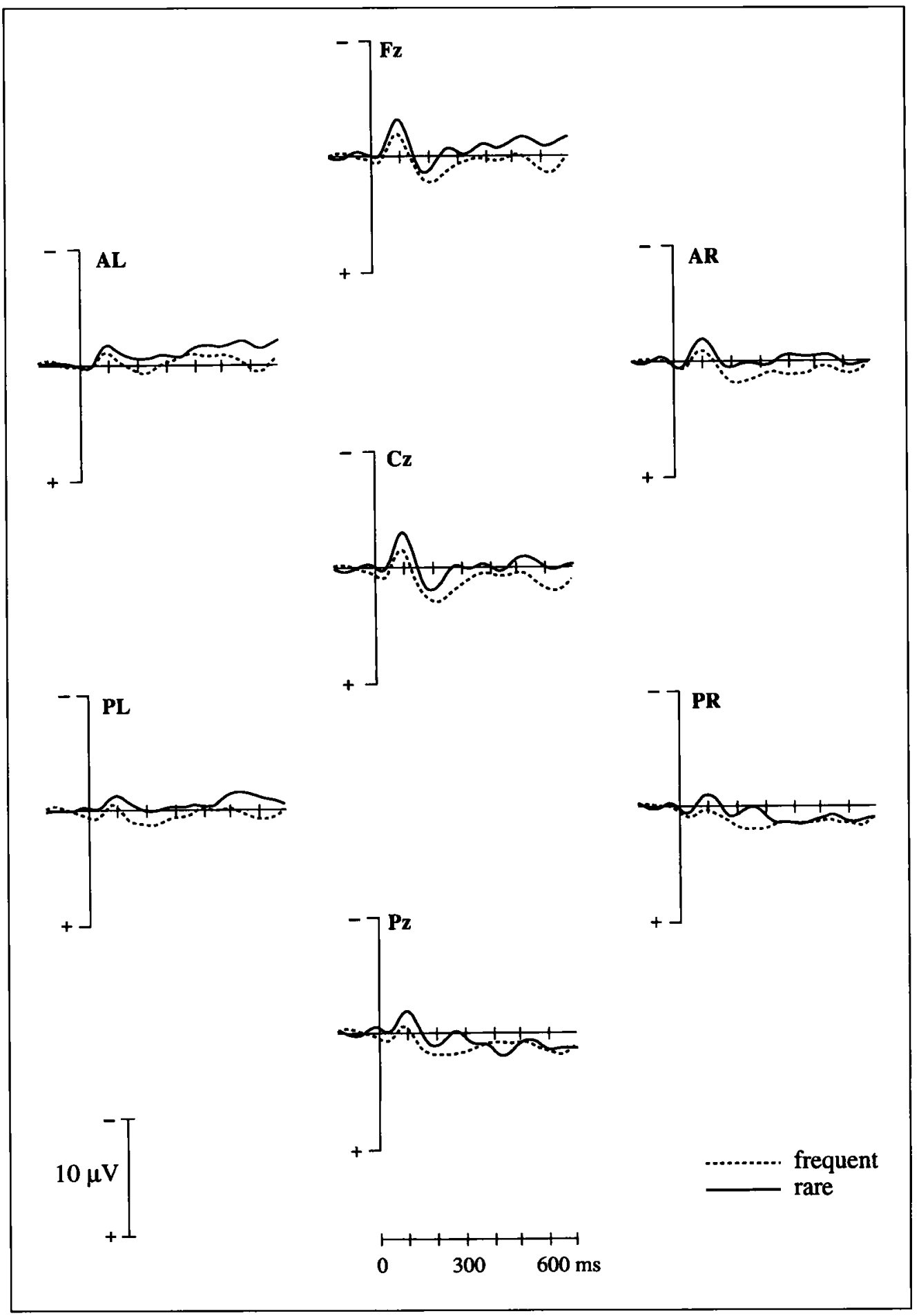

mal P300 effects had no predictive value with respect to the N400 effects, since all subjects with abnormal P300 effects did have $\mathrm{N} 400$ effects.

To further determine to what extent the size of the P300 effect predicted the size of the N400 effect, we computed a correlation for the results averaged over all the electrode sites of the normal controls and the 20 patients (collapsed over the patient groups) in this study. This resulted in the absence of a significant correlation for the normal controls $(R=0.16, p=0.62)$ and for the patients $(R=0.33, p=0.16)$.

Figure 13 shows the difference in the amplitude of the $\mathrm{N} 400$ effect between the early (300-500 ms) and late (500-700 ms) epochs (early-late) over electrode $\mathrm{Cz}$ for each individual subject in the different subject groups. Comparison of the individual data in Figure 13 with the group-averaged data in Figure 5 reveals that although there is some variation, the pattern of results that was 
Figure 11. Individual Subject Data Normal Controls $(\mathrm{N}=$ 12), $\mathbf{R H}=$ Controls $(\mathrm{N}=6)$. Mean amplitude over electrode $\mathrm{Cz}$ of the $\mathrm{N} 400$ effect and the P300 effect for each individual subject in the two control groups. For the right hemisphere patients (RH-controls), subjects 13-18 in this figure correspond with subjects 15-20 in Table 1.
Figure 12. Mean amplitude over electrode $\mathrm{Cz}$ of the N400 effect and the P300 effect for each individual aphasic patient. In this figure subjects 1-7 correspond with subjects $1,2,4,7,9,11$, and 12 in Table 1, and subjects 814 correspond with subjects $3,5,6,8,10,13$, and 14 in the same table.
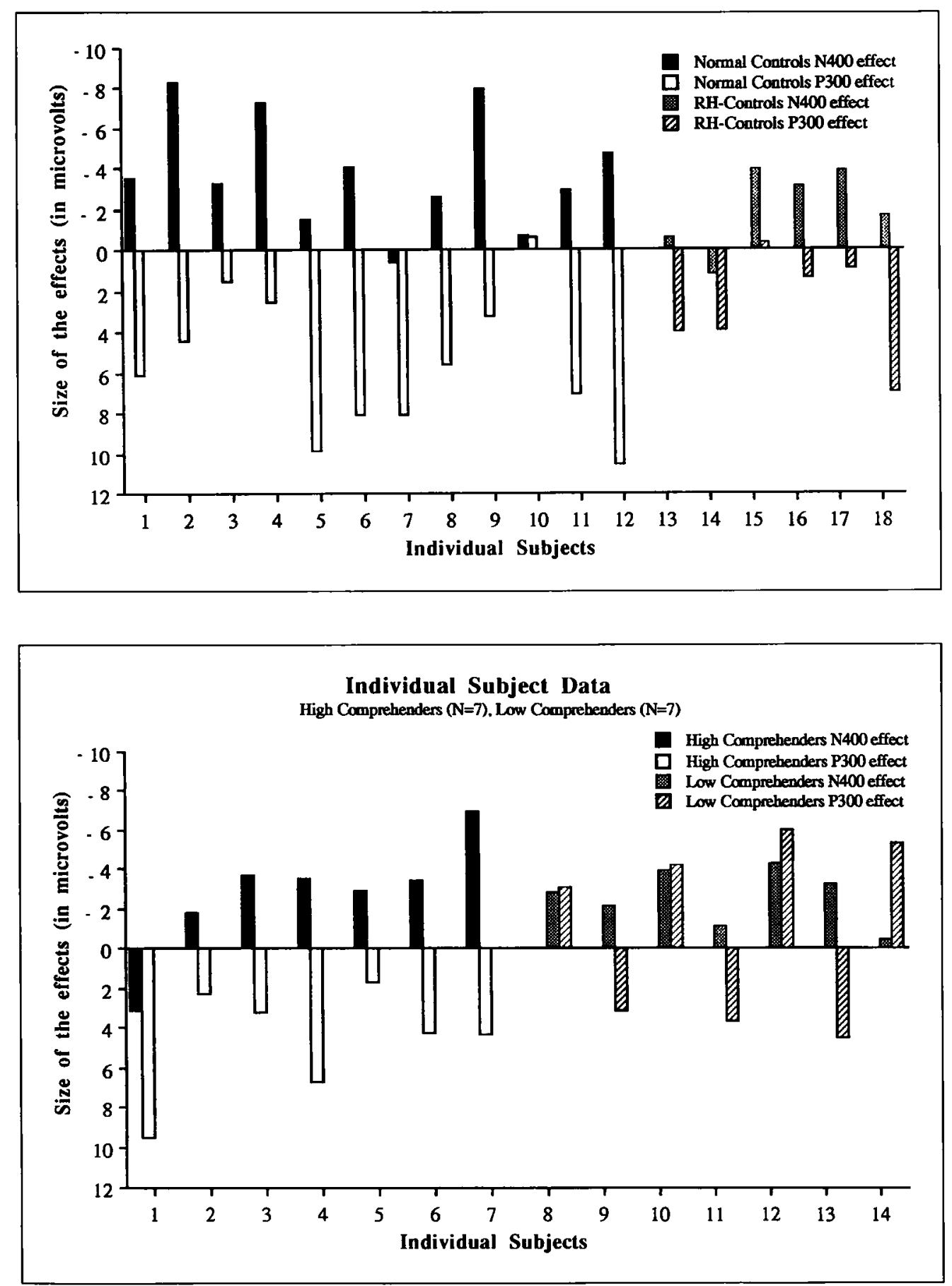

observed in the group averages is discernable in most of the individual subjects. That is, eight of the twelve normal controls, four of the six right hemisphere lesion controls, and six of the seven high comprehenders showed a larger $\mathrm{N400}$ effect in the early relative to the late epoch, and four of the seven low comprehenders showed a larger effect in the late relative to the early epoch.

\section{Questionnaire}

The questionnaire was designed to induce the subjects to listen to the sentences. Subjects knew that questions would be asked, but not when. In order to be able to answer the questions it was therefore important for them to listen attentively to each sentence. Furthermore, each time a question was asked, the subjects were again motivated to listen carefully to the sentences. For the aphasic subjects, the answers to the questions were considered correct even when they contained speech errors (phonemic or semantic paraphasias), agrammatic omissions, and so forth. Furthermore, if these patients repeated part of the sentence, it was also considered a sign that they were listening to the sentences. The mean average of the correct responses was $95 \%$ for the normal 
Figure 13. Individual Subject Differences in Amplitude of the N400 Effect between Early (300-500 ms) and Late (500$700 \mathrm{~ms}$ ) Epoch (Early-Late). In dividual subject differences in the amplitude of the N400 effect between the early (300$500 \mathrm{~ms})$ and late $(500-700$ $\mathrm{ms}$ ) epoch. Subjects above the zero line have an $\mathbf{N} 400$ effect that is larger in the late epoch than in the early epoch. Subjects 1-6 of the right hemisphere patients (RH-controls) correspond with subjects $15-$ 20 in Table 1, for the high comprehenders subjects 1-7 correspond with subjects 1,2 , $4,7,9,11$, and 12 in this table, and for the low comprehenders subjects $1-7$ correspond with subjects $3,5,6,8,10,13$, and 14 in the same table.

controls (range $80-100 \%$ ), $77 \%$ for the right hemisphere lesion controls (range $70-100 \%$ ), $73 \%$ for the high comprehenders (range $40-100 \%$ ), and $63 \%$ for the low comprehenders $(50-100 \%)$. The results show that aphasic patients performed more poorly than normals and right hemisphere lesion controls. This result, however, necessarily reflects their aphasic speech impairment as well. Overall, the results of this questionnaire seem to provide clear evidence that the subjects were attending to the sentences.

\section{DISCUSSION}

The aim of the present study was to investigate realtime spoken sentence understanding in Broca's and Wernicke's aphasics with comprehension deficits. The central question was whether these patients were able to integrate lexical information into a higher order representation of the preceding sentence context, and in addition whether this ability was influenced by the severity of the comprehension deficit in these patients. This was assessed by measuring the N400 to sentencefinal words that were either congruent or anomalous with respect to the preceding sentence context.

The age-matched normal controls showed the expected $\mathrm{N} 400$ congruity effect: The $\mathrm{N} 400$ to sentencefinal congruent words was reduced when compared to the N400 to sentence-final anomalous words. This result is in agreement with the well-documented N400 effect in the literature (Kutas \& Hillyard, 1980) and replicates the finding of Holcomb and Neville (1991), demonstrating that the N400 effect can be obtained when presenting subjects with naturally produced connected speech. In the elderly controls, the $\mathbf{N 4 0 0}$ effect was maximal in the 300-500 ms window, indicating the immediacy of the lexical integration process in normal, neurologically unimpaired subjects.

The nonaphasic patients with a lesion in the right hemisphere also showed a clear $\mathrm{N} 400$ congruity effect. The size of the effect was reduced relative to the normal controls, especially over anterior scalp sites, but this difference was not statistically significant in any of the latency windows. These results indicate that relatively normal N400 effects can be obtained in brain damaged patients without aphasia. Furthermore, although right hemisphere lesioned patients sometimes do show subtle linguistic deficits, for example, in processing purely semantic relations (Chiarello, Burgess, Richards, \& Pollock, 1990; Hagoort et al., 1996), insofar as they are able to integrate lexical meaning into the sentence context, the finding that the latency of the N400 effect does not differ from that of the normal controls suggests that they do so at a normal rate.

The N400 data for the aphasic patients were analyzed according to the severity of their comprehension deficit. This was done for a number of reasons. First, Hagoort et al. (1996) have shown that the severity of the comprehension deficit determined the size of the N400 effect in a word-word priming study. In the current study, we therefore examined whether the severity of the comprehension deficit was correlated with changes in the amplitude and/or the latency of the N400 congruity effect, or in other words, with the ability to integrate lexical information in sentence contexts. Second, since both Broca's and Wernicke's aphasics in our study showed comprehension deficits with varying degrees of severity on a comprehension subtest of the AAT, an analysis in terms of the severity of the comprehension deficit was deemed appropriate.

The aphasic patients with a mild comprehension deficit showed essentially the same pattern of results as 
their controls. That is, neither in size nor in latency did their $\mathrm{N} 400$ effect differ statistically from that of the elderly controls. This shows that relatively normal N400 effects can be obtained in brain damaged patients with aphasia.

The aphasic patients with moderate to severe comprehension deficits also showed a clear $\mathrm{N} 400$ congruity effect. However, these patients differed from all other groups in the latency of the N400 effect. All other groups showed an $\mathrm{N} 400$ effect that had its maximum amplitude in the 300-500 ms epoch. In the low comprehenders, however, the effect had its maximum amplitude in the $500-700 \mathrm{~ms}$ epoch. In these patients the $\mathrm{N} 400$ congruity effect showed a delay of approximately $100 \mathrm{~ms}$ relative to the normal controls and the other patient groups (Figures 5 and 6). Given the speed at which language processing normally occurs (e.g., we can easily recognize four words per second), a delay of this magnitude is quite substantial, and therefore most likely indicative of a problem in deriving an adequate sentence interpretation from the speech input.

Before further interpreting these $\mathrm{N} 400$ results, we need to discuss the $\mathrm{P} 300$ results of the control experiment, in order to establish whether comprehension deficits produced specific effects on the $\mathrm{N400}$ rather than correlated effects on a number of cognitive ERP components, including the P300. The normal controls and the high comprehenders showed a significant P300 effect. Furthermore, the effect of tone probability on the size of the P300 effect was statistically indistinguishable between these groups. The nonaphasic patients with a lesion in the right hemisphere showed a marginally significant $\mathrm{P} 300$ effect that was reduced in size relative to the normal controls. Finally, the low comprehenders did not show any effect at all. In order to evaluate whether the $\mathrm{P} 300$ results provide any problem for interpreting the $\mathrm{N} 400$ results, we examined whether these effects were strongly associated. We found that, on the whole, the P300 effects were dissociable from the N400 effects. For instance, the right hemisphere control subjects showed a clear $\mathrm{N} 400$ effect while the P300 effect was only marginally significant, and the low comprehenders showed a significant N400 effect in the absence of a P300 effect. The dissociation between P300 and N400 effects is further illustrated in the individual subject data (Figures 11 and 12). For example, the five patients who showed "opposite" P300 effects (i.e., negative polarity effects) still showed proper N400 effects, and two patients that showed P300 effects showed "opposite" N400 effects. The absence of a relation was further confirmed by the fact that there was no significant correlation between the size of the P300 and N400 effects for the subjects in this study.

In sum, evaluation of the $\mathrm{P} 300$ and the N400 results supports the following conclusions. First, the high comprehenders had relatively normal ${ }^{5}$ N400 and P300 effects, and this indicates that brain damage alone does not necessarily lead to abnormal cognitive ERP effects, nor does aphasia always lead to a general reduction in all cognitive ERP effects. Furthermore, the absence of a correlation between $\mathrm{P} 300$ and $\mathrm{N} 400$ effects indicates that they are functionally independent in brain damaged patients with and without aphasia, and in neurologically unimpaired subjects. Overall then, the delay of the $\mathbf{N 4 0 0}$ effect in the low comprehenders most likely reflects aspects of their underlying language deficit and not an aspecific effect of their brain damage. With respect to the central question of this study, it is now important to determine what this implies for accounts of comprehension deficits in aphasia. In other words, what do the changes in the $\mathbf{N} 400$ effect of the low comprehenders mean in terms of their language comprehension deficit?

The delay of the N400 effect in the low comprehenders could be explained in terms of a deficit in accessing lexical information. If the process of lexical access is slower than normal in these patients, then the lexical representations would become available for lexical integration at a later moment in time. This would result in a delayed integration of the words throughout the sentence and hence in a delay of the $\mathbf{N 4 0 0}$ congruity effect. However, this interpretation seems unlikely in the light of results from other recent studies, showing that aphasic patients with comprehension problems do not have a deficit in accessing lexical information (e.g., Hagoort, 1993; Tyler et al., 1995). In these studies, priming effects were obtained at short prime-target intervals for patients with severe comprehension deficits. Such effects can only occur if the information in the semantic lexicon was accessed by these patients at a relatively normal time course. Hence, the data of the current study have to be interpreted in different terms. Since the N400 effect is known to be especially sensitive to postlexical integration processes (Brown \& Hagoort, 1993; Chwilla et al., 1995; Holcomb, 1993; Rugg, Furda, \& Lorist, 1988), the results of the present study suggest that the low comprehenders show a relative delay in the integration of lexical meaning into the overall representation of the utterance.

If the N400 effect increases when increased processing is required for integration (Brown \& Hagoort, 1993), one obvious question is why a delay in lexical integration in the low comprehenders resulted in a decreased rather than an increased $\mathbf{N 4 0 0}$ effect relative to the normal controls. One might have expected an increased N400 effect because low comprehenders seem to have more problems than normals in integrating a word into the context. However, the reduction in the $\mathrm{N} 400$ effect can be explained if we consider the effect that delayed integration could have on the processing of the sentence-final congruent and anomalous words. Suppose that a delay in the process of lexical integration yielded an incomplete or degraded higher order context representation for the part of the sentence preceding the final word. Under such circumstances, the notion of congru- 
ent versus anomalous becomes somewhat relative. Note that both sentence-final congruity and sentence-final anomaly is defined in terms of a semantic (mis)match with an adequate representation of the sentence context. However, if the context representation is degraded compared to the normal case, the congruency or anomaly of the final word with respect to the context might become less clear. This results in less of a difference in the $\mathrm{N} 400$ between conditions and hence in a reduced rather than increased $\mathrm{N} 400$ effect.

It is not clear from the present data what underlying mechanism causes the delay in lexical integration in the low comprehenders. However, a number of authors have suggested that comprehension deficits in aphasia might be related to a reduction in computational resources and its effects on the time course of language processing (e.g., Haarmann \& Kolk, 1994; Hagoort, 1990). Hagoort (1990) proposed that relative to lexical access, lexical integration requires more computational resources. During lexical access, prestored lexical information in the mental lexicon is automatically activated. This process is assumed to require computational resources to only a very limited degree. During the process of lexical integration, computational resources are required both to integrate the accessed information into a higher order context representation and to maintain this representation in a temporary buffer. It is therefore reasonable to assume that lexical integration requires more computational resources than lexical access and hence will be more disrupted by a reduction in computational resources than lexical access. As a result, lexical integration will be shifted in time relative to lexical access, which will lead to problems in sentence comprehension.

In conclusion, the delay in the $\mathbf{N 4 0 0}$ effect that the patients with moderate to severe comprehension deficits showed in this study suggests that these patients are slower than normal in the process of integrating lexical information into the overall message representation of a preceding sentence context.

\section{METHODS}

\section{Subjects}

Three groups of subjects participated in this experiment: A group of 12 normal elderly age-matched controls, a group of 6 control subjects with a lesion in the right hemisphere, and a group of 14 aphasic subjects. The testing procedures were approved by the ethical committee of the Nijmegen Academic Hospital. All healthy control subjects and all neurological patients gave informed consent. The elderly control subjects and the right hemisphere patients were paid for their participation. All subject groups were approximately matched with respect to age and level of education. All but one of the elderly control subjects were right-handed according to an abridged version of the Oldfield Handedness
Inventory (Oldfield, 1971). Only the left-handed subject reported familial left handedness. The right hemisphere control patients and the aphasic patients were all (premorbidly) right-handed. According to the responses on a second questionnaire, none of the elderly control subjects had any known neurological impairments or used any neuroleptics. None of the control subjects reported hearing loss or memory problems.

All the patients were tested with the standardized Dutch version of the Aachen Aphasia Test (AAT; Graetz, de Bleser, \& Willmes, 1992). Time of administration was at least six months postonset. Both the presence and type of aphasia were diagnosed on the basis of the AAT-results and on the basis of a transcribed sample of their spontaneous speech. All right hemisphere patients were diagnosed as nonaphasic. Eleven patients with a left hemisphere were diagnosed as Broca's aphasics and three as Wernicke's aphasics. According to their scores on the comprehension subtest of the AAT, 7 of the aphasic patients had a moderate to severe comprehension deficit (LO comprehenders), and 7 had a light to very mild comprehension deficit (HI comprehenders). In the comprehension subtest of the AAT, patients are required to match the linguistic input to one out of four pictures. The linguistic input consists of single words and of sentences, both written and spoken. In Table 1, information on age, gender, scores on the Token Test, performance on the AAT subtest on comprehension (overall scores, sentence comprehension scores, and auditory comprehension scores), and lesion volume is summarized for all the neurological patients. The Token Test is a valid measure of aphasia, independent of syndrome type (Orgass, 1986). The general severity of the aphasia ranged from light to severe. The Token Test results also substantiated that none of the right hemisphere patients was aphasic (Table 1).

The mean age for the normal control subjects was 58.6 years (range: $49-66$ ), the mean age for the right hemisphere patients was 59.5 years (range: 50-71), for the aphasic patients it was 55.2 years (range: 36-73); 53.1 years for the $\mathrm{HI}$ comprehenders (range: $36-72$ ), and 57.3 for the LO comprehenders (range: 38-73).

Figures 14, 15, and 16 give the CT/MRI-lesion data of all the patients for whom adequate CT/MRI information was available. This was the case for 7 high comprehenders, 6 low comprehenders, and 4 right hemisphere patients.

All lesions were due to a cerebral vascular accident (CVA). Lesions evident on CT/MRI scans were transcribed onto corresponding CT/MRI templates by an experienced neurologist. These templates were then read into a computer program that permitted reconstruction of the lateral perspective, determination of lesion volume, and the computation of the group-averaged lesions (Frey, Woods, Knight, Scabini, \& Clayworth, 1987; see Knight, Scabini, Woods, \& Clayworth, 1988 for detail). In all patient groups, the lesions cover a large area 
Table 1. Individual patient information for Broca's aphasics, Wernicke's aphasics, and nonaphasic patients with a right hemisphere lesion. The aphasic patients were clustered on the basis of their comprehension scores into High Comprehenders (HI) and Low Comprehenders (LO)

\begin{tabular}{|c|c|c|c|c|c|c|c|}
\hline Patient & Age & Sex & $\begin{array}{l}\text { Token } \\
\text { Test* }\end{array}$ & $\begin{array}{c}\text { Overall Comp. } \\
\text { Score } A A T^{\star *}\end{array}$ & $\begin{array}{l}\text { Sent. Comp. } \\
\text { Score AAT }\end{array}$ & $\begin{array}{c}\text { Aud. Comp. } \\
\text { Score AAT }\end{array}$ & $\begin{array}{c}\text { Lesion } \\
\text { Volume }^{\star * *}\end{array}$ \\
\hline 01 Broca HI & 40 & m & 17 & $94 / 120$ & $35 / 60$ & $45 / 60$ & 59.60 \\
\hline 02 Broca HI & 36 & f & 19 & $97 / 120$ & $47 / 60$ & $53 / 60$ & 75.10 \\
\hline 03 Broca LO & 62 & $\mathbf{m}$ & 38 & $67 / 120$ & $27 / 60$ & $39 / 60$ & 120.90 \\
\hline 04 Broca HI & 62 & $\mathrm{~m}$ & 20 & $96 / 120$ & $48 / 60$ & $50 / 60$ & 34.60 \\
\hline 05 Broca LO & 38 & f & 31 & $85 / 120$ & $38 / 30$ & $49 / 60$ & 112.10 \\
\hline 06 Broca LO & 69 & $\mathbf{m}$ & 34 & $65 / 120$ & $28 / 60$ & $37 / 60$ & 72.90 \\
\hline 07 Broca HI & 72 & f & 7 & $108 / 120$ & $53 / 60$ & $52 / 60$ & 127.10 \\
\hline 08 Broca LO & 43 & $\mathrm{~m}$ & 41 & $65 / 120$ & $32 / 60$ & $33 / 60$ & 219.05 \\
\hline 09 Broca HI & 53 & $\mathrm{~m}$ & 13 & $98 / 120$ & $55 / 60$ & $49 / 60$ & 49.55 \\
\hline 10 Broca LO & 73 & f & 20 & $87 / 120$ & $42 / 60$ & $41 / 60$ & - \\
\hline 11 Broca $\mathrm{HI}$ & 65 & $\mathbf{m}$ & 25 & $103 / 120$ & $45 / 60$ & $58 / 60$ & 60.35 \\
\hline 12 Wernicke HI & 44 & f & 21 & $99 / 120$ & $47 / 60$ & $48 / 60$ & 64.65 \\
\hline 13 Wernicke LO & 51 & $\mathrm{~m}$ & 43 & $66 / 120$ & $25 / 60$ & $37 / 60$ & 67.20 \\
\hline 14 Wernicke LO & 65 & $\mathbf{m}$ & 45 & - & 一 & $39 / 60$ & 123.65 \\
\hline $15 \mathrm{RH}$-control & 71 & f & 0 & $120 / 120$ & $60 / 60$ & $60 / 60$ & - \\
\hline $16 \mathrm{RH}-$ control & 58 & $\mathbf{m}$ & 0 & $118 / 120$ & $58 / 60$ & $60 / 60$ & 41.10 \\
\hline $17 \mathrm{RH}$-control & 50 & f & 4 & $96 / 120$ & $42 / 60$ & $45 / 60$ & - \\
\hline $18 \mathrm{RH}-$ control & 56 & $\mathbf{m}$ & 1 & $117 / 120$ & $60 / 60$ & $57 / 60$ & 99.65 \\
\hline $19 \mathrm{RH}$-control & 66 & f & 2 & $103 / 120$ & $55 / 60$ & $48 / 60$ & 43.45 \\
\hline $20 \mathrm{RH}$-control & 56 & $\mathbf{m}$ & 1 & $110 / 120$ & $54 / 60$ & $56 / 60$ & 43.25 \\
\hline
\end{tabular}

- Severity of disorder as indicated by the Token Test: no/very mild disorder (0-6); light (7-23); middle (24-40); severe (>40).

** Severity of comprehension disorder as indicated by the AAT subtest Comprehension (includes word and sentence comprehension in both auditory and visual modality); severe (1-66); middle (67-89); light (90-106); no/very mild disorder (107-120).

Ranges of severity are based on the norms of the Dutch version of the AAT (Graetz et al., 1992).

*** Lesion volume in cc. Lesion volume was calculated by using a CT-reconstruction program (see Knight et al., 1988 for detail).

of either the left or the right hemisphere, without a clear focus.

\section{Materials}

The stimuli consisted of a list of 222 auditorily presented Dutch sentences. There were 120 critical sentences, and these critical stimuli were divided over two conditions. In one condition the sentences ended with a word that matched the sentential-semantic constraints, the congruent condition, for example: "The children like to play in the garden." In the other condition, the sentences ended with a word that violated the sentential-semantic constraints, the anomalous condition, for example: "The girl dropped the candy on the sky." In addition, 102 filler sentences were constructed, which contained a semantic violation at varying positions in the sentence. These materials were included to prevent subjects from devel- oping a strategy of predicting the position of the anomalous word. Twelve filler sentences were used as startup items.

The critical sentences were derived from materials that had been submitted to two cloze tests. In each test, 24 subjects from the University of Nijmegen who were paid for their participation, were asked to fill in the first word that came to mind at the position of the omitted sentence-final word after reading the preceding sentence context. From these tests a set of 120 sentences was selected with a cloze probability higher than $29 \%$. The remaining sentences were used to construct the filler items.

Sixty of the 120 sentences that were selected from the cloze tests were assigned to the anomalous condition. In their original (congruent) form, these sentences had a mean cloze probability of $54.6 \%$ (range: $29.2 \%-100 \%$ ). The sixty sentences that were assigned to the congruent 

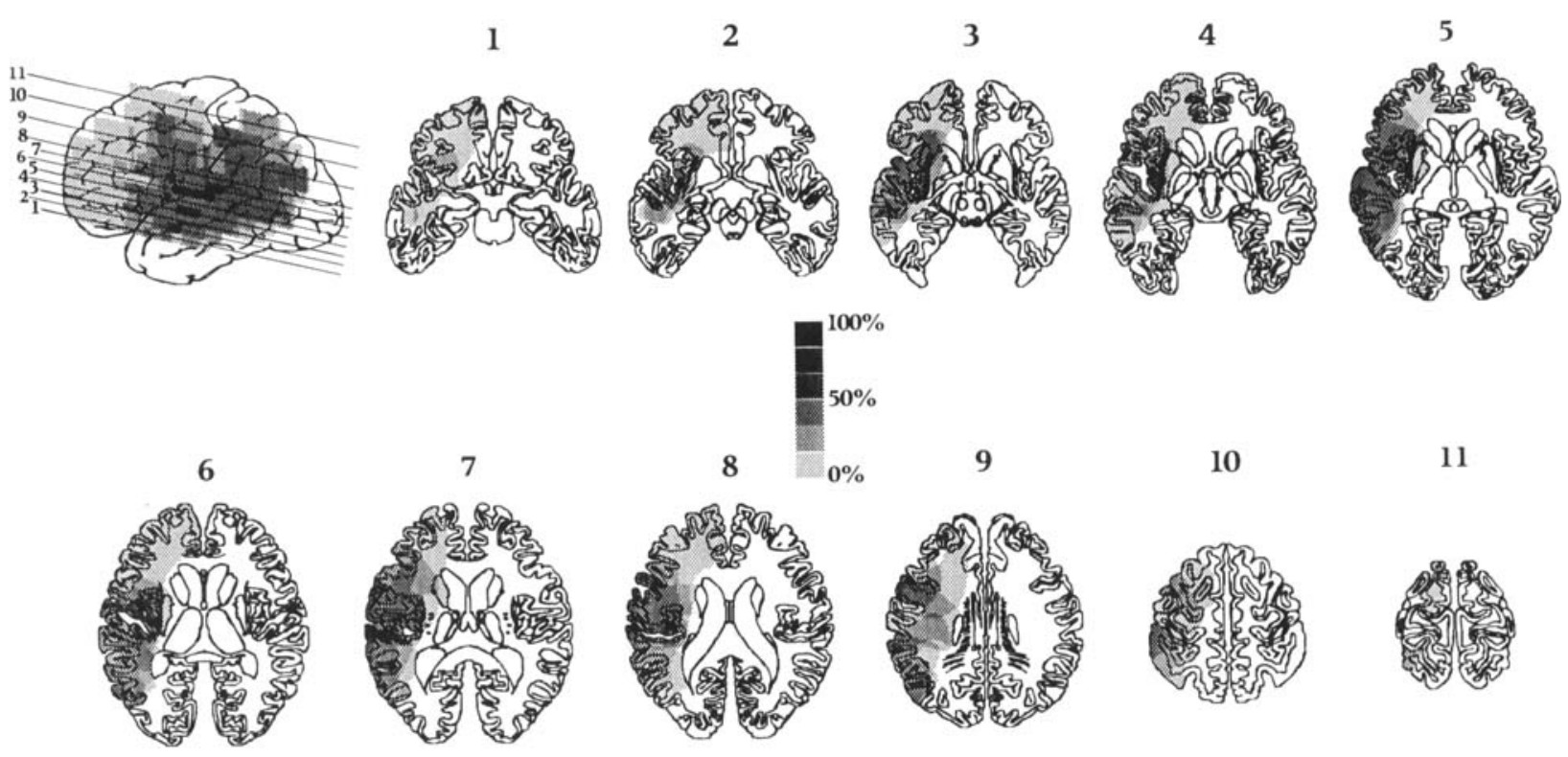

11

Figure 14. Aphasic Patients (High Comprehenders). Lesion extent in the aphasic patients with light to very mild comprehension deficits. Lesions determined by available CT-scans from individual patients were transcribed onto 0 degree to canthomeatal line templates. These lesion data were then read into a reconstruction program. The digitized data were averaged to generate the group lesion densities. The 11 lines through the lateral reconstruction indicate 11 axial sections. The scale indicates the percentage of patients having involvement of that brain region. Lesions were averaged over 7 patients.
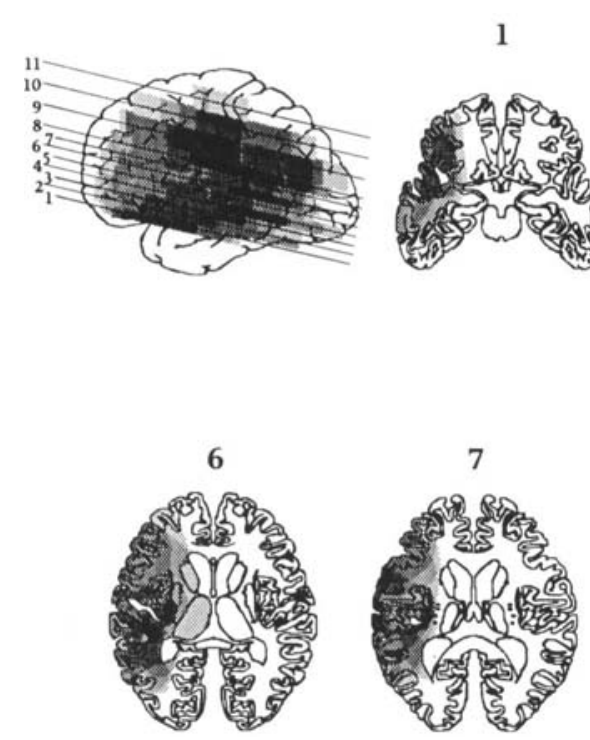

1
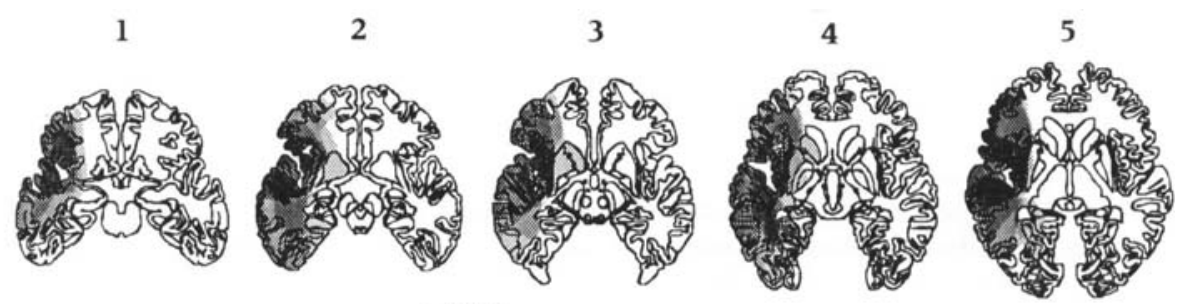

Figure 15. Aphasic Patients (Low Comprehenders). Lesion extent in aphasic patients with moderate to severe comprehension deficits. Lesions were averaged over 6 patients. See Figure 14 for further details.

condition had a cloze probability of $60.3 \%$ (range: $29.9 \%-100 \%)$. So in the original set of sentences, contexts in both conditions were equally constraining for the sentence-final word. The sentences had a syntactic structure that was relatively simple. The syntactic struc- ture was matched between the anomalous and the congruent condition. In the anomalous condition the mean sentence length was 7.8 words (range: 5-10 words), in the congruent condition it was also 7.8 words (range: 6-10 words). The sentences were either active (114 


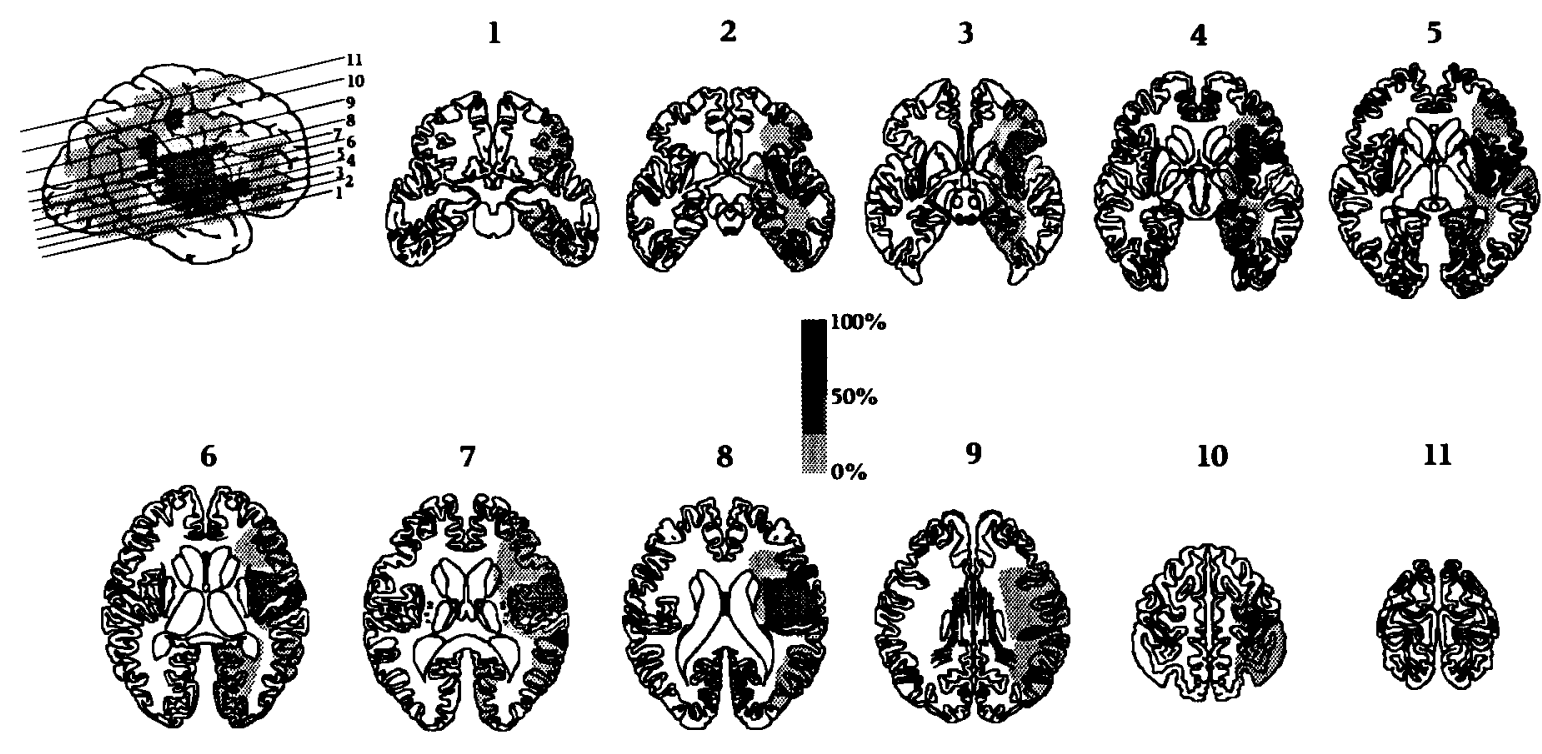

Figure 16. Right Hemisphere Patients. Lesion extent in right hemisphere patients. Lesions were averaged over 4 patients. See Figure 14 for further details.

sentences) or passive ( 6 sentences). These constructions were equally divided over the two conditions. Most of the sentences consisted of a predicate with two arguments. The maximum number of arguments did not exceed three.

In the anomalous condition, the sentence-final words were replaced by words that did not fit the semantic constraints of the preceding context. This resulted in 24 pragmatic and 36 selectional restriction violations. With the exception of four items, the anomalous words did not share any word initial sounds with the original congruent or best completions. There was no associative relationship between the sentence-final word and any of the preceding words in the sentence in all but three of the sentences in the congruent condition. In the anomalous condition the mean lemma frequency of the sentence-final words was 25.1 (s.d.: 37.5 ). In the congruent condition it was 41.8 (s.d.: 37.4 ). The frequencies were established on the basis of Dutch frequency norms for a corpus of 720,000 words (Uit den Boogaart, 1975). The difference between the frequency of the sentence-final words in the anomalous and the congruent conditions was of no real significance to the experiment because the effect of word frequency on N400 amplitude disappears for open class words that occur later in the sentence (Van Petten \& Kutas, 1990).

All the sentence-final words in both conditions were nouns. The length of these words ranged from 3 to 8 characters in both the anomalous and the congruent condition. The mean duration of the sentence-final words in the congruent condition was $489 \mathrm{~ms}$ (s.d.: 81 $\mathrm{ms}$ ), and in the anomalous condition it was $544 \mathrm{~ms}$ (s.d.: $95 \mathrm{~ms}$ ). All the sentence-final words began with a plosive.
In this way the last word in the continuous speech flow was given a natural physical marker that facilitated the alignment of the ERP waveform to the sentence-final word.

The experimental list was preceded by a practice list of 24 sentences, twelve of which contained semantic anomalies. This practice list was used to familiarize the subjects with the experimental situation. For the full set of experimental items, see the Appendix.

The experimental sentences, the fillers and the practice sentences were all spoken by an experienced female speaker, with normal intonation at a normal speaking rate and were recorded in one recording session. In the anomalous condition no specific voice changes marked the sentence-final word as anomalous. Sentences were spoken in a sound attenuating booth and recorded on a digital audiotape. The stimuli were stored in a VAX 750 computer. A speech waveform editing system was used to mark the onset of the sentence-final words. A pulse for triggering the EEG acquisition program was placed at 2909 ms before onset of each sentence-final word. This was the time of the longest sentence until sentencefinal word onset plus a $150 \mathrm{~ms}$ presentence baseline. The interval of silence (ISI) between sentences was $4.6 \mathrm{sec}$. One digital audiotape was made containing the experimental list preceded by the practice items.

In order to induce the subjects to listen to the sentences during the experiment, a questionnaire was constructed, with five questions about anomalous and five about congruent filler sentences (see Results).

In addition to the test tape with the sentence stimuli, a digital audiotape was constructed with tones. This tape contained 300 tones, 60 tones of $1 \mathrm{kHz}$ and 240 tones 
of $2 \mathrm{kHz}$. The tones were presented in a random order with a frequency of one per second and a duration of $20 \mathrm{~ms}$. A trigger pulse was placed $150 \mathrm{~ms}$ before the onset of each tone. The 300 experimental tones were preceded by a practice set of 50 tones (10 tones of $1 \mathrm{kHz}$ and 40 tones of $2 \mathrm{kHz}$ ) to familiarize the subjects with the stimuli and the task.

\section{Procedure}

The subjects were tested individually in a dimly illuminated sound-attenuating booth and were seated in a comfortable reclining chair. Three patients were tested in their wheelchairs. Subjects were instructed to move as little as possible and to keep their eyes fixated on a point at eye-level $1.5 \mathrm{~m}$ in front of them. Subjects were told that they would hear sentences, some of which had words in them that did not fit the context. They were asked to listen attentively to the sentences, and they were told that the experimenter would sometimes stop the tape to ask them a question about a sentence they had just heard. No additional tasks were imposed. For the tone oddball task, subjects were asked to listen to the tones and silently count the low ones. All the stimuli were presented via a DAT-recorder (SONY 300ES). The subjects listened to the stimuli via a closed-ear Sennheiser HMD-224 headphone. The trigger pulse on the right channel of the test tapes was inaudible to the subjects.

All the subjects were tested in one session of about two hours. The total time of stimulation was about 35 minutes, including the practice list ( $2 \min 26 \mathrm{sec}$ ), the experimental list $(27 \mathrm{~min})$ and the tones $(5 \mathrm{~min})$. A session started with the practice list to familiarize the subjects with the stimulus situation and to train them to fixate their eyes during sentence presentation. If necessary, the practice list was repeated for the patients. Every two to four minutes, a question was asked about the contents of a filler sentence to verify that the subjects were listening to the sentences. The answer was written down by the experimenter. After each question it was again stressed to the subjects to listen carefully to the sentences. If necessary, a short break was given after asking a question. All the subjects were given a break after 14 minutes of stimulation in the experimental list and before the tone oddball. The practice session of the tone oddball was used to establish whether patients were able to silently count the low tones. Five patients were unable to count. For these subjects it was established that they could discriminate high versus low tones (by raising a hand for the low tones during practice), and they were instructed to listen attentively, without an additional task.

\section{EEG-Recording}

The EEG was recorded from 7 tin electrodes in an electrode cap. Each electrode was referred to the left mastoid. Three electrodes were placed according to the International 10-20 system (Jasper, 1958) over midline sites at $\mathrm{Fz}, \mathrm{Cz}$, and $\mathrm{Pz}$ locations. Four were placed laterally over symmetrical anterior and posterior positions. The symmetrical anterior electrodes (AL, AR) were located one half of the distance between $\mathrm{F} 7$ and $\mathrm{T} 3$, and $\mathrm{F} 8$ and T4 sites. The symmetrical posterior electrodes (PL, PR) were located $30 \%$ of the interaural distance lateral to a point $13 \%$ of the nasion-inion distance posterior to $\mathrm{Cz}$. Vertical and horizontal eye movements were monitored via sub- and supra-orbital electrodes, and left and right external canthal montages, respectively. The ground electrode was placed on the forehead, $10 \%$ of the nasion-inion distance above the nasion.

The EEG and EOG recordings were amplified by $\mathrm{Ni}$ hon Kohden AB-601G bioelectric amplifiers, using a time constant of 8 seconds and low-pass cutoff of $30 \mathrm{~Hz}$. Impedances were kept below $5 \mathrm{kOhm}$. The signal was digitized on-line with a sample frequency of $200 \mathrm{~Hz}$. The trigger pulse started sampling $150 \mathrm{~ms}$ before the presentation of a sentence. The total sampling epoch per trial was $5350 \mathrm{~ms}$ for the sentence stimuli and $1000 \mathrm{~ms}$ for the tones. Data were stored along with condition codes for subsequent off-line averaging and data analysis.

\section{Appendix}

\section{Anomalous Sentences}

1. Jenny stopte het snoepje in haar BLOEM

2. Er staat een lange rij voor het KONIJN

3. De kok eet zijn macaroni met een KAARS

4. Midden in het park staat een BOEK

5. De toneelspeelster verkleedde zich achter het BLOED

6. Het gereedschap wordt bewaard in de KAAS

7. Opa vertelde zijn kleinkinderen een fantastisch BURO

8. De vader gaf zijn jarige dochter een KELDER

9. Pannen worden verkocht in de garage achter de PATIENT

10. Jeroen stal verschillende staven goud uit de KIKKER

11. De familiefoto staat op de TRAAN

12. De agenten doorzochten op grondige wijze het KLIMAAT

13. De koningin bezocht de laatste uitvoering van het PUIN

14. Meestal slaapt de hond in de TOERIST

15. Anne kraste haar naam in de deur met haar TOMAAT 16. Met gemak sprong Annette over de brede KLINIEK 17. De jongen makkte een dreigende beweging met zijn KIP

18. Miriam moest veel betalen voor de reparatie van haar KELNER

19. Eline lijmde snel de kapotte KNECHT

20. De jongen vraagt de politie om DRAMA

21. De wesp viel bij mijn zusje in de DIJK

22. De baby lag heerlijk te slapen in de DRANK 
23. Als hij in de tuin werkt draagt Sjors BROOD

24. Het antal zieke kinderen neemt toe in de BRIEF

25. De dief kwam het huis binnen via het PUBLIEK

26. Het was onmogelijk het eiland te bereiken vanwege de DROOM

27. Het meisje op de schommel roept haar BEKER

28. De verhuizer zette het schilderij tegen de KEIZER

29. De dief verstopte zich in de DUIVEL

30. Met een net ving de man de PLAS

31. Het meisje borstelt de TABEL

32. De japanse toneelspeler droeg een bijzonder TERRAS

33. Er zit een vliegje in mijn DANS

34. De moeder gaf haar kind de DREMPEL

35. De matroos heeft pijn in zijn KRAAG

36. Wij gaan iedere week een keer naar de BOTER

37. Er wordt een nieuwe brug gemaakt bij de BROMMER

38. Het warenhuis heeft een afdeling voor de PLANEET

39. Tegenwoordig drinken de kinderen elke dag KOPER

40. Langzaam reed de vrachtwagen door de TEKST

41. Het kind is erg bang voor het DEEG

42. Omdat ze te laat kwam kreeg Marian DRUPPELS

43. De jongen botste hard tegen de PRUIK

44. De fiets van het meisje staat tegen de BRUID

45. De leraar gaf het kind een PLEIN

46. De bruine boterham is belegd met PAKJES

47. De plastic emmer zit vol met KOORTS

48. De vrouw loopt graag langs het PROTEST

49. De gevaarlijke dieren zitten in een PATER

50. De tentoonstelling werd gehouden in de grote KO-

GEL

51. De meeste kampeerspullen liggen op TABAK

52. De olifant lag te slapen in de PRINS

53. In bedrukte stemming stonden de mannen rond het POTLOOD

54. De boeren onderhandelden lang over de prijs van de BUI

55. Vlug kroop de kleine muis in het TARIEF

56. Mijn oom schreeuwde hard tegen zijn BAARD

57. De mooie valk zit op het BEDRAG

58. In het voorjaar broeden hier veel KOEKEN

59. Wij bereikten de elfde verdieping met de PERZIK

60. Er werken meer dan 1000 arbeiders in de moderne KOUS

\section{Congruent Sentences}

1. De timmerman kreeg een compliment van zijn BAAS

2. De oude vrouw krijgt iedere middag BEZOEK

3. De voorzitter werd ontslagen door het BESTUUR

4. Het meisje bond de hond vast aan de BOOM

5. Als het mooi weer is huren we vaak een BOOT

6. Na de sprong had Jan een gat in zijn BROEK

7. Op het nachtkastje in de hotelkamer ligt een BIJBEL

8. De vrouw makkte van de takken een flinke BOS

9. Het meisje speelt vaak bij de BUREN

10. De flatbewoner zit bij mooi weer graag op het BALKON
11. Bij het skiën brak het meisje haar rechter BEEN

12. De buurman brouwt sinds kort zijn eigen BIER

13. De koeien worden iedere morgen gemolken door de BOER

14. Dit eiland is met het vasteland verbonden door een BRUG

15. Op de hoek van de straat komt een warme BAKKER

16. De moeder zag het kind spelen met een BAL

17. De poes sprong zonder problemen op het DAK

18. De moeder kreeg een lange brief van haar DOCHTER

19. De spoorlijn loopt dwars door het DORP

20. Woedend trapte Hans een gat in de DEUR

21. De jongen veegde zijn mond af met een DOEK

22. De radio werd verpakt in een DOOS

23. Er meldden zich veel sprekers voor het CONGRES

24. Ik ga meestal naar dezelfde KAPPER

25. Geduldig hielp de ober de lastige KLANT

26. Deze schilder heeft veel gevoel voor KLEUR

27. Op zijn achtiende ging de vrome jongen in het KLOOSTER

28. Na aankomst droeg de vrouw de zware KOFFER

29. De man koopt iedere ochtend een KRANT

30. De kinderen vormden met zijn allen een KRING

31. De schrijfster kan slecht tegen KRITIEK

32. De rijke verzamelaar is een groot liefhebber van moderne KUNST

33. Ik eet meestal in de KEUKEN

34. Bij Marcel bleef het snoepje steken in zijn KEEL

35. De zwerver heeft geen geld voor nieuwe KLEREN

36. Na lang zoeken vond de student een geschikte KAMER

37. De miljonair kocht op de veiling een antieke KLOK 38. Nederlanders drinken s'morgens graag en veel KOFFIE

39. De schildwacht stond uren bij de poort van het KASTEEL

40. De zakenman droeg een mooi grijs PAK

41. De koetsier zorgt goed voor zijn PAARDEN

42. Je mag niet zwemmen in de vijver van het PARK

43. De moeder verzorgde de billetjes van de baby met POEDER

44. In de werkkamer liggen overal stukjes PAPIER

45. Voor de vakantie bedacht Stef een mooi PLAN

46. In de vensterbank staat een mooie PLANT

47. De dominee houdt zondags vaak een lange PREEK

48. Veel boeren halen het water uit een zelfgeslagen PUT 49. De gevangenen in Rusland krijgen tegenwoordig een eerlijk PROCES

50. Ineke heeft een speciale mand voor haar POES

51. De poes bleef zitten op de bovenste PLANK

52. De voetballers namen deel aan een groot TOERNOOI

53. De kinderen spelen graag in de TUIN

54. Met een flinke zwaai gooide Wilma haar tas op TAFEL

55. De oude man heeft nog maar één TAND

56. Tegen het zwartrijden rijden er conducteurs mee op de TRAM

57. Mijn oma drinkt s'avonds alleen maar THEE 
58. De roeier verhoogde allengs zijn TEMPO

59. Per ongeluk trapte Rene op mijn TEEN

60. De jager stopte zorgvuldig de patronen in de TAS

\section{Acknowledgments}

This research was performed at the Max Planck Institute for Psycholinguistics, within the "Neurocognition of Language Processing" research group, and was supported by grants 560264-040 and 400-56-384 from the Netherlands Organization for Scientific Research (NWO). T.S. was supported by a fellowship of the James S. McDonnell Foundation during the writing of this paper. We are grateful to Peter Praamstra and Mariken ter Keurs for providing CT/MRI scans and transcribing these scans onto templates, to Robert Knight for his assistance and support, and for making available his CT/MRI reconstruction algorithm, to Aafke Deckers for construction of the sentences in the language experiment, to Annemieke Nevejan and Hanneke Wentink for testing the patients with the AAT, and to Clif Kussmaul and Rene de Bruin for technical assistance. We would also like to thank Marta Kutas, Ron Mangun, Phil Holcomb, and Michael Gazzaniga for their advice and support.

Reprint requests should be sent to Tamara Swaab, Center for Neuroscience, University of California, 1544 Newton Court, Davis, California 95616. E-mail: swaab@marzen.ucdavis.edu

\section{Notes}

1. No ANOVAs will be reported for the Broca's and the Wernicke's aphasics separately. Inspection of the individual subject data revealed that the results for the 3 Wernicke's aphasics were not qualitatively different from those of the 11 Broca's aphasics in this study, as was further substantiated by the absence of a significant Aphasia Syndrome by Congruity interaction $(F<1)$ in an ANOVA with Aphasia Syndrome (Broca, Wernicke) as the additional factor. Analyses of the data on the basis of the comprehension scores of the aphasic patients, independent of type of syndrome, is therefore justified.

2. This also holds for the patient groups.

3. After a Greenhouse Geisser correction (1959), only the normal controls showed a significant Congruity by Electrode site interaction for the 300-700 ms epoch $(F(1,11)=6.32, M S e$ $=0.63, p<0.05)$, and the 300-500 ms epoch $(F(1,11)=7.11$, $M S e=0.70, p<0.05$ ), indicating the centroparietal distribution of the effect. This interaction did not reach significance in any of the patient groups, even though in the right hemisphere lesion controls and the high comprehenders there also seemed to be a centroparietal distribution of the effect. The absence of a significant interaction in these groups might reflect the reduced power of the test due to the smaller group size. In the face of these statistical analyses, no strong claims will be based on the topographical distribution of the N400-effect in these groups. Moreover, given the unknown lesion consequences on volume conduction, we will not attach any functional significance to distributional differences between patient groups and only describe the distributional aspects of the effects.

4. After a Greenhouse-Geisser correction (1959), only the normal controls showed a significant Tone Probability by Electrode site interaction $(F(1,11)=10.74, M S e=1.71, p<0.01)$, indicating that the $\mathrm{P} 300$ effect was larger at centroparietal sites than at anterior sites. None of the patient groups showed this interaction. No strong claims will be based on the topographical distribution of the $\mathrm{P} 300$ effect in these groups.

5. Since the patient groups consisted of only 6 (right hemisphere controls) or 7 (high comprehenders and low com- prehenders) subjects, the power of the between group comparisons was relatively low, and therefore our ability to detect differences between the groups is somewhat limited. This is why we use some caution in interpreting the effects in the high comprehenders and the right hemisphere lesion controls as normal, even though no statistically significant Group of Subjects by Congruity interaction were observed between these groups and the group of normal controls.

\section{REFERENCES}

Allison, T., Wood, C. C., \& McCarthy, G. M. (1986). The central nervous system. In M. G. M. Coles, E. Donchin, \& S. W. Porges (Eds.), Psychopbysiology: systems, processes, and applications. New York: Guilford.

Balota, D. A., \& Chumbley, J.I. (1984). Are lexical decisions a good measure of lexical access? The role of word frequency in the neglected decision stage. Journal of Experimental Psycbology: Human Perception and Performance, 10, 340-357.

Baum, S. R. (1989). On-line sensitivity to local and long distance syntactic dependencies in Broca's aphasia. Brain and Language, 37, 327-338.

Bentin, S., McCarthy, G., \& Wood, C. C. (1985). Event-related potentials, lexical decision and semantic priming. Electroencephalograpby and Clinical Neuropbysiology, 60 343-355.

Berndt, R. S., \& Caramazza, A. (1980). A redefinition of the syndrome of Broca's aphasia: Implications for a neuropsychological model of language. Applied Psycholinguistics, 1, 225-278.

Besson, M., \& Macar, F. (1987). An event-related potential analysis of incongruity in music and other nonlinguistic contexts. Psycbophysiology, 24, 14-25.

Blumstein, S. E., Milberg, W. P., Dworetzky, B., Rosen, A., \& Gershberg, F. (1991). Syntactic priming effects in aphasia: An investigation of local syntactic dependencies. Brain and Language, 40, 393-421.

Blumstein, S. E., Milberg, W., \& Shrier, R. (1982). Semantic processing in aphasia: Evidence from an auditory lexical decision task. Brain and Language, 17, 301-315.

Boddy, J. (1986). Event-related potentials in chronometric analysis of primed word recognition with different stimulus onset asynchronies. Psychopbysiology, 23, 232-245.

Brown, C. M., \& Hagoort, P. (1993). The processing nature of the N400: evidence from masked priming. Journal of Cognitive Neuroscience, 5, 34-44.

Chenery, H. J., Ingram, J. C. L., \& Murdoch, B. E. (1990). Automatic and volitional semantic processing in aphasia. Brain and Language, 38, 215-232.

Chiarello, C., Burgess, C., Richards, L., \& Pollock, A. (1990). Semantic and associative priming in the cerebral hemispheres: Some words do, some words don't . . . sometimes, some places. Brain and Language, 38, 75-104.

Chwilla, D. J., Brown, C. M., \& Hagoort, P. (1995). The N400 as a function of the level of processing. Psycbopbysiology, 32, 274-285.

de Groot, A. M. B. (1984). Primed lexical decision: The combined effects of the proportion of related prime-target pairs and the stimulus-onset asynchrony of prime and target. Quarterly Journal of Experimental Psycbology: Human Experimental Psychology, 36A, 253-280.

Fischler, I., \& Bloom, P. A. (1980). Rapid processing of the meaning of sentences. Memory and Cognition, 8, 216225.

Frauenfelder, U. H., \& Tyler, L. K. (1987). The process of spo- 
ken word recognition: An introduction. Cognition, 25, 120.

Frey, R. T., Woods, D. L., Knight, R. T., Scabini, D., \& Clayworth, C. C. (1987). Defining functional areas with averaged CTscans. Society for Neuroscience Abstract, 13, 1266.

Friederici, A. D., \& Kilborn, K. (1989). Temporal constraints on language processing: Syntactic priming in Broca's aphasia. Journal of Cognitive Neuroscience, 1, 262-272.

Friederici, A. D., \& Frazier, L. (1992). Thematic analysis in agrammatic comprehension: Syntactic structures and task demands. Brain and Language, 42, 1-29.

Friedman, R. B., Glosser, G., \& Diamond, H. (1988). Semantic versus associative lexical priming in Alzheimer's disease and fluent aphasia. Paper presented at the Annual Meeting of the Academy of Aphasia, Montreal, Canada.

Goodglass, H., \& Baker, E. (1976). Semantic field, naming, and auditory comprehension in aphasia. Brain and Language, 3, 359-374

Graetz, P., de Bleser, R., \& Willmes, K. (1992). Akense afasie test. Lisse: Swets \& Zeitlinger.

Graf, P., \& Mandler G. (1984). Activation makes words more accessible, but not necessarily more retrievable. Journal of Verbal Learning and Verbal Bebavior, 23, 553-568.

Gratton, G., Coles, M. G. H., \& Donchin, E. (1983). A new method for off-line removal of ocular artifact. Electroencephalography and Clinical Neuropbysiology, 55, 468-484.

Greenhouse, S. W., \& Geisser, S. (1959). On methods in the analysis of profile data. Psycbometrika, 24, 95-112.

Grober, E., Perecman, E., Kellar, L., \& Brown, J. (1980). Lexical knowledge in anterior and posterior aphasics. Brain and Language, 10, 318-330.

Gunter, T. C., Jackson, J. L., \& Mulder, G. (1992). An electrophysiological study of semantic processing in young and middle-aged academics. Psychopbysiology, 29, 38-54.

Haarmann, H. J., \& Kolk, H. H. J. (1991). Syntactic priming in Broca's aphasics: Evidence for slow activation. Apbasiology, 5, 247-263.

Haarmann, H. J., \& Kolk, H. H. J. (1994). On-line sensitivity to subject-verb agreement violations in Broca's aphasia: The role of syntactic complexity and time. Brain and Language, 46, 493-516.

Hagoort, P. (1990). Tracking the time course of language understanding in aphasia. Ph.D. Thesis, Nijmegen University.

Hagoort, P. (1993). Impairments of lexical-semantic processing in aphasia: Evidence from the processing of lexical ambiguities. Brain and Language, 45, 189-232.

Hagoort, P., Brown, C. M., \& Groothusen, J. (1993). The syntactic positive shift (SPS) as an ERP measure of syntactic processing. Language and Cognitive Processes, 8, 439483.

Hagoort, P., Brown, C. M., \& Swaab, T. Y. (1996). Lexical-semantic event-related potential effects in patients with left hemisphere lesions and aphasia, and patients with right hemisphere lesions without aphasia. Brain, 119, 627-649

Hagoort, P., \& Kutas, M. (1995). Electrophysiological insights into language deficits. In F. Boller, \& J. Grafman (Eds.), Handbook of neuropsychology (Vol. 10, pp. 105-134). Amsterdam: Elsevier.

Holcomb, P. J. (1993). Semantic priming and stimulus degradation: Implications for the role of the N400 in language processing. Psychopbysiology, 30, 47-61.

Holcomb, P. J., \& Neville, H. J. (1991). Natural speech processing: An analysis using event-related brain potentials. Psycbobiology, 19, 286-300.

Jasper, H. H. (1958). Report to the committee on methods and clinical examination in electroencephalography. Appendix: The ten-twenty system of the International Federation.
Electroencephalograpby and Clinical Neuropsychology, 10, 371-375.

Katz, W. F. (1988). An investigation of lexical ambiguity in Broca's aphasics using an auditory lexical priming technique. Neuropsycbologia, 26, 747-752.

Knight, R. T., Scabini, D., Woods, D. L., \& Clayworth, C. C. (1988). The effects of lesions of superior temporal gyrus and inferior parietal lobe on temporal and vertex components of the human AEP. Electroencephalograpby and Clinical Neurophysiology, 70, 499-509.

Knight, R. T., Scabini, D., Woods, D. L., \& Clayworth, C. C. (1989). Contributions of the temporal-parietal junction to the human auditory P3. Brain Research, 502, 109-116.

Kutas, M., \& Hillyard, S. A. (1980). Reading senseless sentences: Brain potentials reflect semantic incongruity. Science, 207, 203-205.

Kutas, M., \& Hillyard, S. A. (1983). Event-related brain potentials to grammatical errors and semantic anomalies. Memory and Cognition, 11, 539-550.

Linebarger, M. C., Schwartz, M. F., \& Saffran, E. M. (1983). Sensitivity to grammatical structure in so-called agrammatic aphasics. Cognition, 13, 361-392.

Lukatela, K., Crain, S., \& Shankweiler, D. (1988). Sensitivity to inflectional morphology in agrammatism: Investigation of a highly inflected language. Brain and Language, 33, 1-15.

Marslen-Wilson, W. (1987). Functional parallelism in spoken word-recognition. Cognition, 25, 71-102.

McClelland, J. L., \& Elman, J. L. (1986). Interactive processes in speech perception: The TRACE model. In J. L. McClelland, D. E. Rumelhart, \& the PDP Research Group (Eds.), Parallel distributed processing: Explorations in the microstructure of cognition (Vol. 2). Cambridge, MA: MIT Press.

Milberg, W., \& Blumstein, S. E. (1981). Lexical decision and aphasia: Evidence for semantic processing. Brain and Language, 14, 371-385.

Milberg, W., Blumstein, S. E., \& Dworetzky, B. (1987). Processing of lexical ambiguities in aphasia. Brain and Language, 31, 138-150.

Milberg, W., Blumstein, S., Katz, D., Gershberg, F, \& Brown, T. (1995). Semantic facilitation in aphasia: Effects of time and expectancy. Journal of Cognitive Neuroscience, 7, 33-50.

Moss, H. E., \& Marslen-Wilson, W. D. (1993). Access to word meanings during spoken language comprehension: Effects of sentential semantic context. Journal of Experimental Psychology: Learning, Memory, \& Cognition, 19, 12541276.

Neely, J. H. (1977). Semantic priming and the retrieval from lexical memory: Roles of inhibitionless spreading activation and limited-capacity attention. Journal of Experimental Psychology: General, 106, 226-254.

Neely, J. H. (1991). Semantic priming effects in visual word recognition: A selective review of current findings and theories. In D. Besner, \& G. Humphreys (Eds.), Basic processes in reading: Visual word recognition. Hillsdale, $\mathrm{NJ}$ : Lawrence Erlbaum Associates.

Oldfield, R. C. (1971). The assessment of the analysis of handedness: The Edinburgh inventory. Neuropsycbologia, 9, 97113.

Orgass, B. (1986). Der token test. Weinheim: Beltz.

Osterhout, L., \& Holcomb, P. J. (1992). Event-related brain potentials elicited by syntactic anomaly. Journal of Memory and Language, 31, 785-806.

Ostrin, R. K., \& Tyler, L. K. (1993). Automatic access to lexical semantics in aphasia: Evidence from semantic and associative priming. Brain and Language, 45, 147-159.

Rugg, M. D., Furda, J., \& Lorist, M. (1988). The effects of task on the modulation of event-related potentials by word repetition. Psychopbysiology, 25, 55-63. 
Schwanenflugel, P. J., \& Shoben, E. J. (1985). The influence of sentence constraint on the scope of facilitation for upcoming words. Journal of Memory and Language, 24, 232252.

Shankweiler, D., Crain, S., Gorrell, P., \& Tuller, B. (1989). Reception of language in Broca's aphasia. Language and Cognitive Processes, 4, 1-33.

Stanovich, K. E., \& West, R. F. (1983). On priming by a sentence context. Journal of Experimental Psychology: General, 112, 1-36.

Swaab, T. Y., Brown, C. M., \& Hagoort, P. (1995). Delayed integration of lexical ambiguities in Broca's aphasics: Evidence from event-related potentials. Brain and Language, 51, 159-161.

Swinney, D. A., Zurif, E., \& Nicol, J. (1989). The effects of focal brain damage on sentence processing: An examination of the neurological organization of a mental module. Journal of Cognitive Neuroscience, 1, 25-37.

Tyler, L. K., \& Ostrin, R. K. (1994). The processing of simple and complex words in an agrammatic patient: Evidence from priming. Neuropsycbologia, 32, 1001-1013.
Tyler, L. K., Ostrin, R. K., Cooke, M., \& Moss, H. E. (1995). Automatic access of lexical information in Broca's aphasics: Against the automaticity hypothesis. Brain and Language, 48, 131-162.

Uit den Bogaart, P. C. (1975). Woordfrequenties in geschreven en gesproken Nederlands. Oosthoek: Scheltema \& Holkema.

Van Petten, C., \& Kutas, M. (1990). Interactions between sentence context and word frequency in event-related brain potentials. Memory and Cognition, 18, 380-393.

Van Petten, C., \& Kutas, M. (1991). Influences of semantic and syntactic context on open- and closed-class words. Memory and Cognition, 19, 95-112.

Winer, B. J. (1971). Statistical principles in experimental design. New York: McGraw-Hill.

Zurif, E. B., Caramazza, A., Myerson, R., \& Galvin J. (1974). Semantic feature representations for normal and aphasic language. Brain and Language, 1, 167-187.

Zwitserlood, P. (1989). The locus of the effects of sententialsemantic context in spoken-word processing. Cognition, $32,25-64$. 